\title{
Biodegradation of Pharmaceutical Wastes in Treated Sewage Effluents by Bacillus subtilis 1556WTNC
}

\author{
Adel A. S. Al-Gheethi • Norli Ismail
}

Received: 10 June 2014 / Accepted: 2 September 2014 / Published online: 23 September 2014

(C) Springer International Publishing Switzerland 2014

\begin{abstract}
The aim of this study was to investigate the potentials for enzymatic biodegradation of pharmaceutical active compounds ( $\beta$-lactam antibiotics) in treated sewage effluents as a function of $\beta$-lactamase produced Bacillus subtilis 1556WTNC. Four $\beta$-lactams antibiotics were selected: two of them belong to penicillin's (amoxicillin and ampicillin) and two belong to cephalosporins (cephalexin and cefuroxime); ciprofloxacin (belongs to quinolones) was used as a negative control. The enzymatic biodegradation process was conducted under the optimal conditions for $\beta$-lactams production $\left(5.9 \log _{10} \mathrm{CFU} \mathrm{mL} \mathrm{m}^{-1}\right.$; $\mathrm{pH} 6.5$; temperature $35{ }^{\circ} \mathrm{C}$ for 12 days) as determined in this research. The maximum biodegradation was $25.03 \%$ at $1 \mathrm{mg} \mathrm{mL}^{-1}$ for amoxicillin, $15.59 \%$ at $0.8 \mathrm{mg} \mathrm{mL}{ }^{-1}$ of ampicillin, $22.59 \%$ at $1 \mathrm{mg} \mathrm{mL}^{-1}$ of cephalexin, $10.62 \%$ at $1 \mathrm{mg} \mathrm{mL}^{-1}$ of cefuroxime, while it was $2.45 \%$ at $0.6 \mathrm{mg} \mathrm{mL}^{-1}$ of ciprofloxacin. B. subtilis 1556 WTNC exhibited the potential to produce $\beta$-lactamase and biodegrade $\beta$-lactam antibiotic genetically and inducibly $B$. subtilis $1556 \mathrm{WTNC}$ could grow and biodegrade $\beta$-lactam antibiotics in conditions similar to the characteristics of treated sewage effluents such as $\mathrm{pH}$, temperature, and during short time (12 days), because it was already acclimatized to those conditions. For this reason, treated sewage effluents were used as source to isolate this strain. It can be concluded that $B$. subtilis $1556 \mathrm{WTNC}$ is suitable to remove pharmaceutical residues from the treated sewage effluents and produce effluents at higher quality than that achieved by secondary treatment process.
\end{abstract}

Keywords $\beta$-lactam antibiotics $\cdot \beta$-lactamase $\cdot B$. subtilis $1556 \mathrm{WTNC} \cdot$ Treated sewage effluent

\section{Introduction}

High amount of pharmaceuticals in the environment relate to the incessant consumption of these drugs by individuals, especially antibiotics (Toloti and Mehrdadi 2001). Due to high

\footnotetext{
A. A. S. Al-Gheethi $(\bowtie) \cdot$ N. Ismail

Environmental Technology Division, School of Industrial Technology, University Science Malaysia (USM), Penang, Malaysia

e-mail: adelalghithi@gmail.com
}

Adel A. S. Al-Gheethi

e-mail: aasa1982@yahoo.com

N. Ismail

e-mail: norlii@usm.my 
amount of antibiotics released in the environment, the adverse effect cannot be ignored as antibiotic resistant microbes evolve. Sewage treatment plants (STPs) are considered as one of the most important sources of antibiotic-resistant bacteria in the environment. Most of antibiotics are structurally complex organic chemicals that are resistant to degradation during the sewage treatment process (Cokgor et al. 2004; Spongberg and Witter 2008). Many antibiotics, e.g., amoxicillin, ampicillin, oxacillin, cloxacillin, cephapirin, ciprofloxacin, erythromycin, trimethoprim and cloxacillin (Giger et al. 2003; Cha et al. 2006; Karthikeyan and Meyer 2006; Watkinson et al. 2007; Li and Zhang 2010) have been found in treated sewage effluents.

Adequate treatment technologies that will rid humans from exposure to antibiotic in the environment are required. For this purpose, many techniques have evaluated for removal of $\beta$ lactam antibiotic from sewage effluents; among them, ozonation (Dodd et al. 2006), UV irradiation (Batt et al. 2007) and biosorption process (Al-Gheethi et al. 2014). However, it is observed that these techniques are often highly expensive, insufficient and some of them produce toxic by-products. For example, several investigators have reported considerable removal of antibiotics by UV disinfection method in wastewaters (Batt et al. 2007; Le-Minh et al. 2010). The ozonation and chlorination processes may lead to the production of carcinogenic compounds (Pehlivanoglu-Mantas et al. 2006). Al-Gheethi et al. (2014) reported that the biosorption process could efficiently remove heavy metals from treated sewage effluents but not cephalexin antibiotics. Hence, the need arises to try the application of enzymatic biodegradation of antibiotics present in treated sewage effluents.

Up to date, there is dearth of information on the ability of microorganisms in conversion of pharmaceutical active compounds in wastewater; as such, more technological advance research is needful to explore microbe potential. Many bacteria have been reported to produce $\beta$ lactamases to reduce the pharmacological potency of the $\beta$-lactam antibiotics (Neu 1992). The enzymatic treatment is applicable to bio-refractory compounds found in antibiotics and is potent even at high or low concentrations and operation over a wide range of $\mathrm{pH}$, temperature and salinity (Karam and Nicell 1997).

The increased loads of antibiotics in sewage effluents create the selective pressure for the survival of bacteria in a contaminated environment (Giger et al. 2003; Cha et al. 2006; Karthikeyan and Meyer 2006; Watkinson et al. 2007; Li and Zhang 2010). These contaminants are extended into the treated sewage effluent, thus, giving treated sewage effluents containing a high diversity of bacteria. Some of these bacteria may be resistant to antibiotics (Silva et al. 2006; Rajbanshi 2008; Al-Bahry et al. 2009; Börjesson 2009; Velickovic-Radovanovic et al. 2009).

The study aims to explore treated sewage effluents as a potential source to isolate, identify and test the ability of the most potent bacterial strain, as well as to determine the optimum conditions for this strain to be most effective in biodegradation of pharmaceutical residues in treated sewage effluents by using $\beta$-lactamase. Novel technologies in enzyme biotreatment are efficacious and produce new methods in sewage treatment.

\section{Materials and Methods}

\subsection{Selection of the Most Potent Bacterial Strain}

The methodology at this stage focused on the selection of the most potent bacterial strain that have the ability to produce an enzyme extractive for use in biological sewage treatment process and testing the results. The enzyme under consideration is $\beta$-lactamase. For this purpose, 68 
bacterial isolates were obtained from 21 treated sewage effluent samples collected from three sewage treatment plants (STPs) at Penang, Malaysia. The treated sewage effluent samples were well mixed using shaker $(10 \mathrm{~min} / 125 \mathrm{rpm})$ to distribute the bacteria uniformly prior to analysis. Thirty $\mathrm{mL}$ of the sample was transferred to first dilute $270 \mathrm{~mL}(\mathrm{v} / \mathrm{v})$ sterilized distilled water (U.S. EPA 2003). The dilution was shaken for $10 \mathrm{~min} / 125 \mathrm{rpm} .0 .1 \mathrm{~mL}$ of first diluent was pipetted using a micropipette $(100-1,000 \mu \mathrm{L}$, Eppendorf research, Germany) and blue tips (pre-sterilised, disposable plastic), spread with glass spreader (sterilised with alcohol flaming) onto the surface of N-A medium M001 (Hi media laboratories; Pvt, Ltd India) (dried before inoculation for $24 \mathrm{~h}$ at $35^{\circ} \mathrm{C}$ to absorb all the water of the inoculum). Plates were incubated (Memert-Germany) to $24-48 \mathrm{~h}$ at $35^{\circ} \mathrm{C}$.

The purification of bacterial isolates obtained from treated sewage effluent samples was carried out according to APHA (1999). After the incubation period of $24 \mathrm{~h}$ at $35^{\circ} \mathrm{C}$, a single bacteria colony was checked for its purity using Gram staining and the same pure colony was stock on two slants of McCartney tubes $(28 \mathrm{~mL})$ containing BHI agar (M211, Hi media laboratories; Pvt, Ltd India) in a refrigerator at $4{ }^{\circ} \mathrm{C}$ for further studies.

The susceptibility of the bacterial isolates against amoxicillin $(50 \mu \mathrm{g})$, ampicillin $(50 \mu \mathrm{g})$, cephalexin $(50 \mu \mathrm{g})$, cefuroxime $(50 \mu \mathrm{g})$, and ciprofloxacin $(30 \mu \mathrm{g})$ were carried out by the disk diffusion susceptibility test on NA medium according to Morse and Jackson (2003).

To identify tolerant bacteria for cephalexin and producing $\beta$-lactamase, bacterial isolates were grown on Dox's cephalexin yeast extract medium containing the following (in $\mathrm{g} \mathrm{L}^{-1}$ ): $\mathrm{NaNO}_{3}: 2 ; \mathrm{KCl}: 0.5 ; \mathrm{MgSO}_{4}: 0.5 ; \mathrm{K}_{2} \mathrm{HPO}_{4}: 1.0$ (R\&M Marketing, Essex, UK); yeast extract: 1 (Merck, Germany); and cephalexin: 1 incubated at $35^{\circ} \mathrm{C}$ for 7 days. Bacterial growth was estimated as aforementioned. Bioassay of the enzyme was carried out by using iodometric test (Tube method) according to Ogawara (1975).

Fifteen bacterial strains were selected for further studies and identified based on biochemical test by using API system. To investigate the ability of bacterial strains to produce the enzyme inducibly or genetically, the bacterial strains were grown in the same previous medium with replacement of cephalexin by glucose $\left(1 \mathrm{~g} \mathrm{~L}^{-1}\right)$.

To exam bacterial strains that have growth and production for the enzyme in the treated sewage effluents, bacterial strains that genetically produced the enzyme were sub-cultured in treated sewage effluents containing in $\mathrm{g} \mathrm{L}^{-1}$ : $\mathrm{NaNO}_{3}: 2 ; \mathrm{KCl}: 0.5 ; \mathrm{MgSO}_{4}: 0.5 ; \mathrm{K}_{2} \mathrm{HPO}_{4}: 1.0$; yeast extract,: 1.0 and cephalexin: 1 . This medium named effluent cephalexin yeast extract (ECY) medium (similarly to DCY medium, except that the distilled water was replaced by treated sewage effluent).

To survey bacterial strains that have the ability for enzymatic biodegradation of cephalexin in the treated sewage effluents, bacterial strains which exhibit the ability to produce $\beta$-lactamase in treated sewage effluents were inoculated in the sewage effluents (no nutrients elements were added, except of $1 \mathrm{~g} \mathrm{~L}^{-1}$ cephalexin). Fifty $\mathrm{mL}$ of the sewage effluent were dispensed in flasks of $250 \mathrm{~mL}$ capacity. The $\mathrm{pH}$ was adjusted to $6.5,1 \mathrm{mg} \mathrm{mL}^{-1}$ of cephalexin was added, and a loopful of each studied bacterial strain was used as an inoculum for each flask, incubated at $35^{\circ} \mathrm{C}$ for 15 days. The flasks were covered with aluminium foil to minimise exposure to light and prevent photo-degradation of antibiotics, according to Gobel et al. (2005). The concentrations of $\beta$-lactamase in the treated sewage effluent samples, biodegradation percentage, amount of bacterial growth and biomass yield were determined as stated below.

The most potent bacterial strain (stain No. 1556WTNC) which secrete the highest yield of $\beta$-lactamase in ECY medium and has the ability for enzymatic biodegradation of cephalexin in the treated sewage effluent was confirmed by analysis of $16 \mathrm{~S}$ rRNA sequences by using PCR technique (bacterial strain No.1556 WTNC was sent to Profound Kestrel Laboratories Sdn Bhd for this purpose). 


\subsection{Factors Affecting Production of $\beta$-Lactamase}

Before commencing the enzymatic degradation studies, the factors affecting the production of $\beta$-lactamase (inocula size of bacteria, incubation periods, $\mathrm{pH}$ and temperatures) were determined. $50 \mathrm{~mL}$ of treated sewage effluent sterilized by autoclave was used as production medium, $1 \mathrm{~g} \mathrm{~L}^{-1}$ cephalexin was added as sole carbon source. The production of $\beta$ lactamase was investigated at different inocula sizes $\left(0.75,1.49,2.99,5.98\right.$ and $7.48 \log _{10}$ CFU mL $\left.{ }^{-1}\right)$ during different incubation periods (1, 2, 4, 8, 10, 12 and 20 days), at different $\mathrm{pH}$ values $(4,4.5,5,5.5,6,6.5,7,7.5$ and 8$)$. $\beta$-lactamase production was also investigated at different temperatures, namely $25,30,35,40$ and $45^{\circ} \mathrm{C}$.

\subsection{Biodegradability Studies}

Biodegradation was carried out using inoculum prepared from stock culture of stain No. 1556WTNC. The sterilized treated sewage effluents were inoculated by stain No. 1556WTNC, incubated on incubator shaker $(150 \mathrm{rpm})$ at $35{ }^{\circ} \mathrm{C}$ for $72 \mathrm{~h}$. The inoculum volume was $5.98 \log _{10} \mathrm{CFU} \mathrm{mL}-1 / 50 \mathrm{~mL}$ of every batch experiment) as determined in the last step (section 2.2).

Biodegradation of the selected antibiotics (amoxicillin, ampicillin, cephalexin, cefuroxime and ciprofloxacin) in treated sewage effluent samples was investigated at different concentrations $\left(0.2,0.4,0.6,0.8,1,2,3,4\right.$ and $\left.5 \mathrm{mg} \mathrm{mL}^{-1}\right)$. The initial volume of the treated sewage effluent was $50 \mathrm{~mL}$ for every batch. The selected antibiotics were added to treated sewage effluent samples after sterilization process in order to prevent the degradation of antibiotics during steam autoclave sterilization. Aseptically precaution was adhering during the transfer of inoculum into the sterilized effluent. Aerobic condition was use for enzymatic biodegradation and the effluent contents were thoroughly mixed $(200 \mathrm{rpm})$. The flasks were covered by aluminium foil to prevent photo-degradation. The initial $\mathrm{pH}$ of the effluent was maintained at 6.5 . At the end of incubation period (12 days), treated sewage samples were analyzed for $\beta$-lactamase concentrations, biodegradation, bacterial growth, $\mathrm{pH}$ and biomass yield. The results obtained were used to compare with the enzymatic biodegradation effectiveness of the $\beta$-lactams antibiotics on-inoculated sample (used as blank) and ciprofloxacin, which was used as a negative control.

\subsection{Analytical methods}

\subsubsection{B-lactamase Concentrations}

$\beta$-lactamase concentrations (EC 3.5.2.6) were determined by measuring the hydrolysis of cephalexin according to Çelik and Çalik (2004). Samples of the treated sewage effluents were harvested by centrifugation at 13,500 (rpm) for $10 \mathrm{~min}$. Fresh substrate solutions were prepared daily and maintained at $30{ }^{\circ} \mathrm{C}$, by dissolving $0.4 \mathrm{mg} \mathrm{mL} \mathrm{mL}^{-1}$ cephalexin in $0.1 \mathrm{M}$ phosphate buffer, $\mathrm{pH} 7.0 .0 .1 \mathrm{~mL}$ of the sample was added to $3 \mathrm{~mL}$ of substrate solution and immediately analysed by following the change in absorbance in one minute at $340 \mathrm{~nm}$ with a spectrophotometer (MERCK NOVA 60). The reaction mixtures containing heat-inactivated post-culture liquids (boiled for $5 \mathrm{~min}$ ) were used as blank. One unit of $\beta$-lactamase concentrations was defined as the amount of enzyme that could hydrolyse $1 \mu \mathrm{mol}$ of cephalexin at $30{ }^{\circ} \mathrm{C}$ and $\mathrm{pH} 7.0$ in one minute. 


\subsubsection{Biodegradation (\%)}

Biodegradation was calculated based on results of enzyme concentrations by applying the following equation:

$$
\text { Biodegradtion }(\%)=\frac{\text { Antibiotichydrolyzing }\left(\mathrm{mg} \mathrm{mL}^{-1}\right)}{\text { Antibioticsubstrate }\left(\mathrm{mg} \mathrm{mL}^{-1}\right)} \times 100
$$

\subsubsection{Bacterial Growth and Biomass Yield}

The bacterial growth was estimated by using the direct plating technique on Nutrient Agar (NA) medium (Merck-Germany) and expressed in unit CFU $\mathrm{mL}^{-1}$. The biomass yield was determined by using the dry weight method. After collection of supernatant, the biomass residue was dried at $80{ }^{\circ} \mathrm{C}$ for $24 \mathrm{~h}$ and the yield was expressed as $\mathrm{mg} / 100 \mathrm{~mL}$ of the treated sewage effluent.

\subsection{Data Analysis}

All analyses were carried out in triplicate and values reported as means with standard deviations. Data were subjected to one way analysis of variance (ANOVA) in the general linear model using the SPSS 11.5 statistical package. The statistical package (EASE, M-STAT) was used to perform the analyses of least significance difference (LSD). ANOVA was used to determine the significance $(p<0.05)$ of the differences between results.

\section{Results}

\subsection{Selection of the Most Potent Bacteria Strain}

The maximum resistance among Gram-positive bacterial isolates were recorded against cefuroxime (100\%), while among Gram-negative bacteria the maximum resistance was noted for ampicillin $(81.63 \%)$. Both Gram-positive and Gram-negative bacteria exhibited the minimum resistance to ciprofloxacin (5 and $8.1 \%$ ). The bacterial isolates investigated in this work, exhibited more resistance to cefuroxime and ampicillin compared to ciprofloxacin. About $83.82 \%$ of the bacterial isolates in the current study were multi-resistant (resistant to three antibiotics or more). More Gram-positive than Gram-negative bacteria exhibit multiresistance to antibiotics under study (100 vs. $77.55 \%$ ) (data not shown).

Figure $1 \mathrm{a}$ and $\mathrm{b}$ represent the results of screening process for production of $\beta$-lactamase in DCY medium among the bacterial isolates obtained from treated sewage effluents. About 42 (almost $61.19 \%$ ) of the 68 isolates were tolerant to cephalexin and exhibited high growth (more than $5 \log _{10} \mathrm{CFU} \mathrm{mL} \mathrm{m}^{-1}$ ) in the presence of cephalexin; among them, 41 bacterial isolates produced $\beta$-lactamase at different degrees. The bacterial isolates Nos. 1050, 625, $1558,1556,101,211,519,210,842$ and $903 \mathrm{~W}$ exhibited high growth and production of $\beta$ lactamase.

The amount of $\beta$-lactamase produced by different bacterial isolates in this work differed significantly as determined by ANOVA $(p<0.01)$. Among the 40 bacterial isolates, which showed positive results to the presence of $\beta$-lactamase, $10(24.39 \%)$ produced more than 0.33 $\mathrm{U} \mathrm{mL}^{-1}, 19$ (46.34\%) produced between 0.16 and $0.33 \mathrm{U} \mathrm{mL}^{-1}$ and $12(29.26 \%)$ produced less than $0.16 \mathrm{U} \mathrm{mL}^{-1}$. 


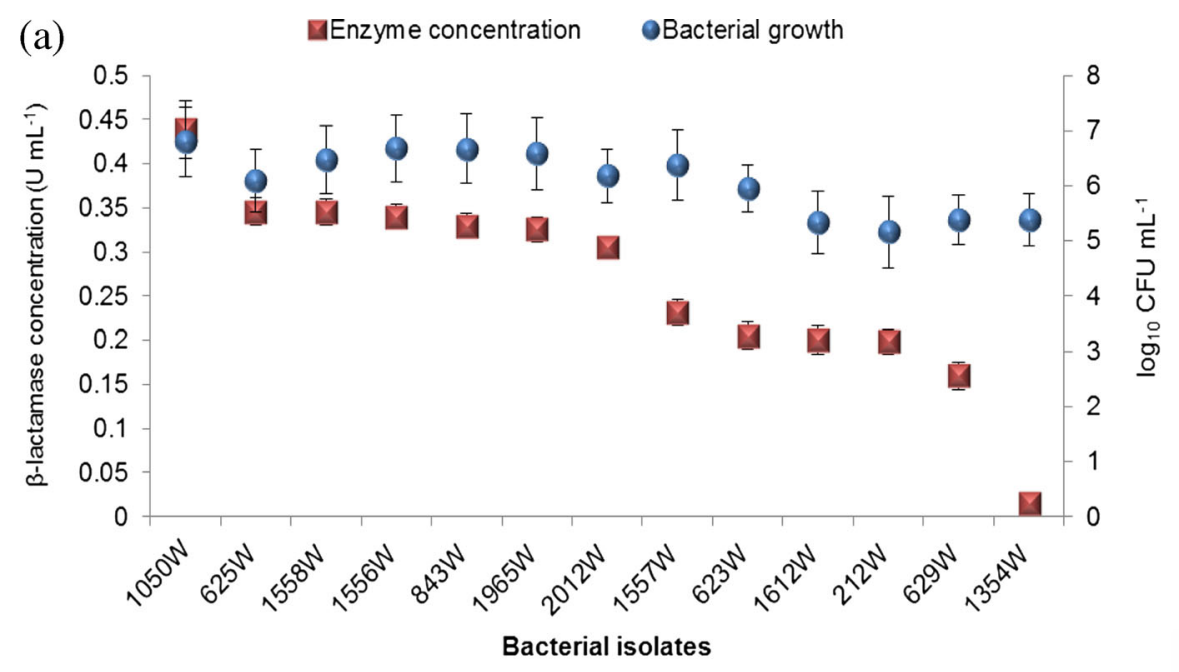

(b)

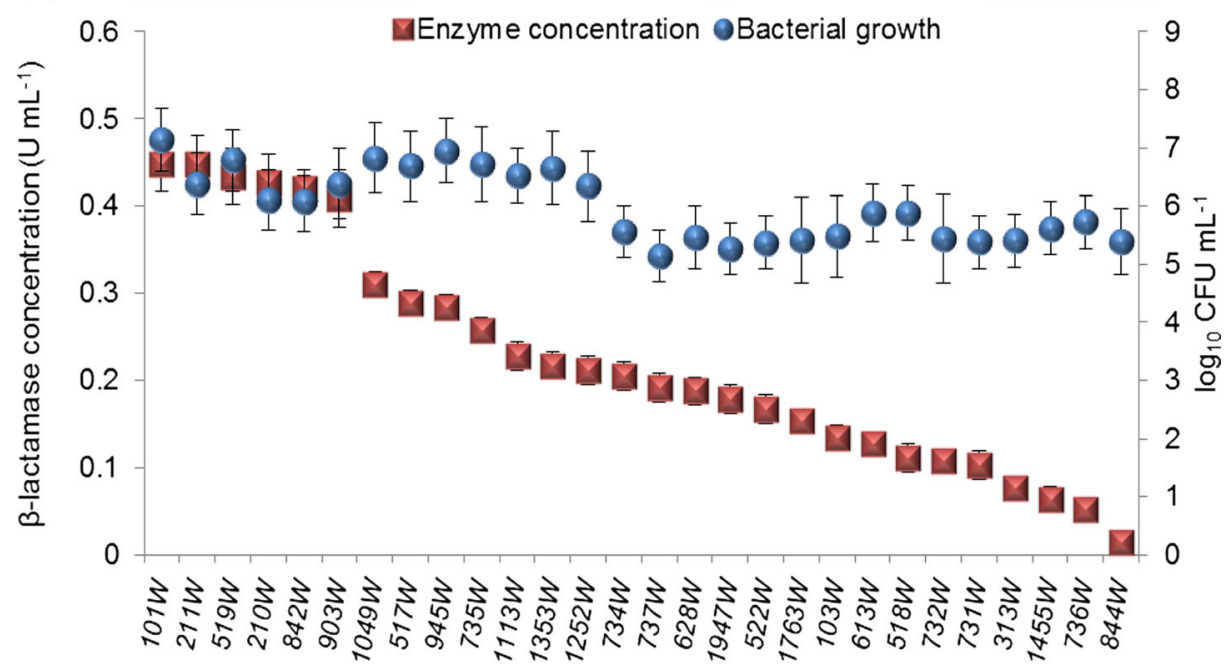

Bacterial isolates

Fig. 1 Bacterial growth and $\beta$-lactamase production by bacterial isolates obtained from three STPs in PenangMalaysia in the presence of $\left(1 \mathrm{~g} \mathrm{~L}^{-1}, \mathrm{w} / \mathrm{v}\right)$ cephalexin. a) Gram positive bacteria, b) Gram-negative bacteria

Fifteen bacterial strains were selected for further studies and were identified based on biochemical tests by using API system (Tables 1, 2 and 3). These strains belonged to six genera (Bacillus sp., Pseudomonas sp., Chryseomonas sp., Burkholderia sp., Citrobacter sp., and Kluyvera sp.). These bacterial strains were tested for the ability to produce $\beta$-lactamase as genetically or inducible. The results (Fig. 2) indicate that B. sterothermophilus $1050 \mathrm{WTNC}$ and $B$. cepacia 503WTNCcould still synthesize $\beta$-lactamase at varying degrees. Bacterial strain $C$. luteota $313 \mathrm{WTNC}$ and $C$. luteota $613 \mathrm{WTNC}$ appeared to lose the ability to produce 


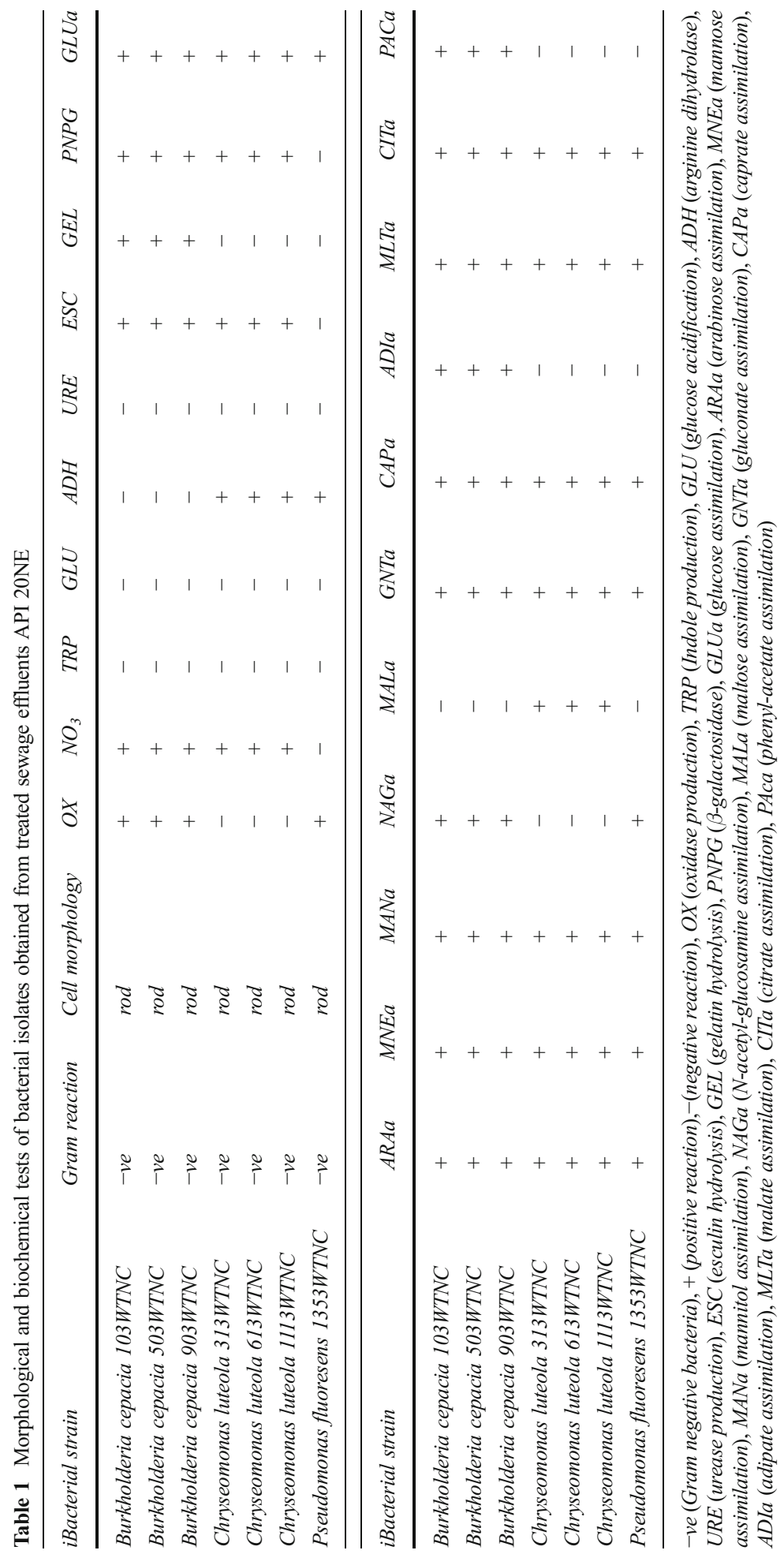




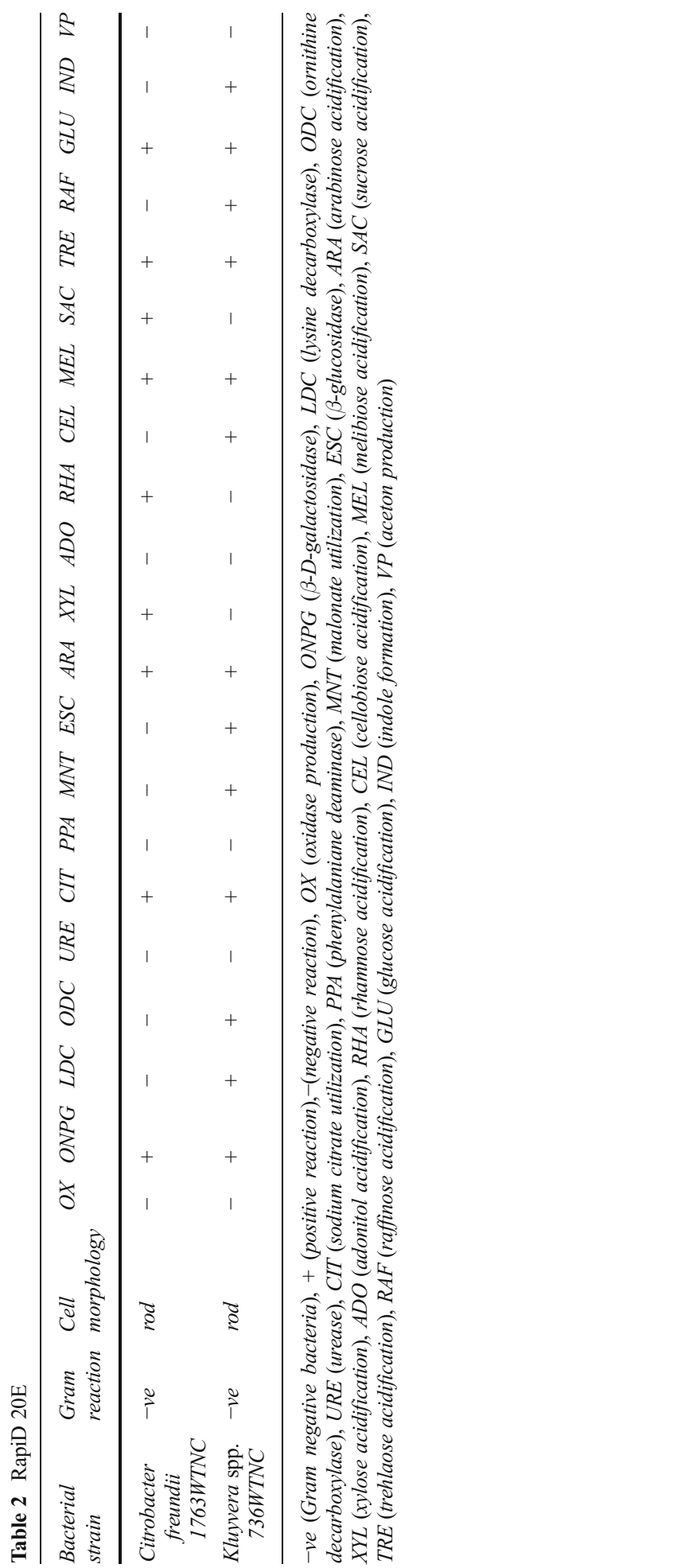




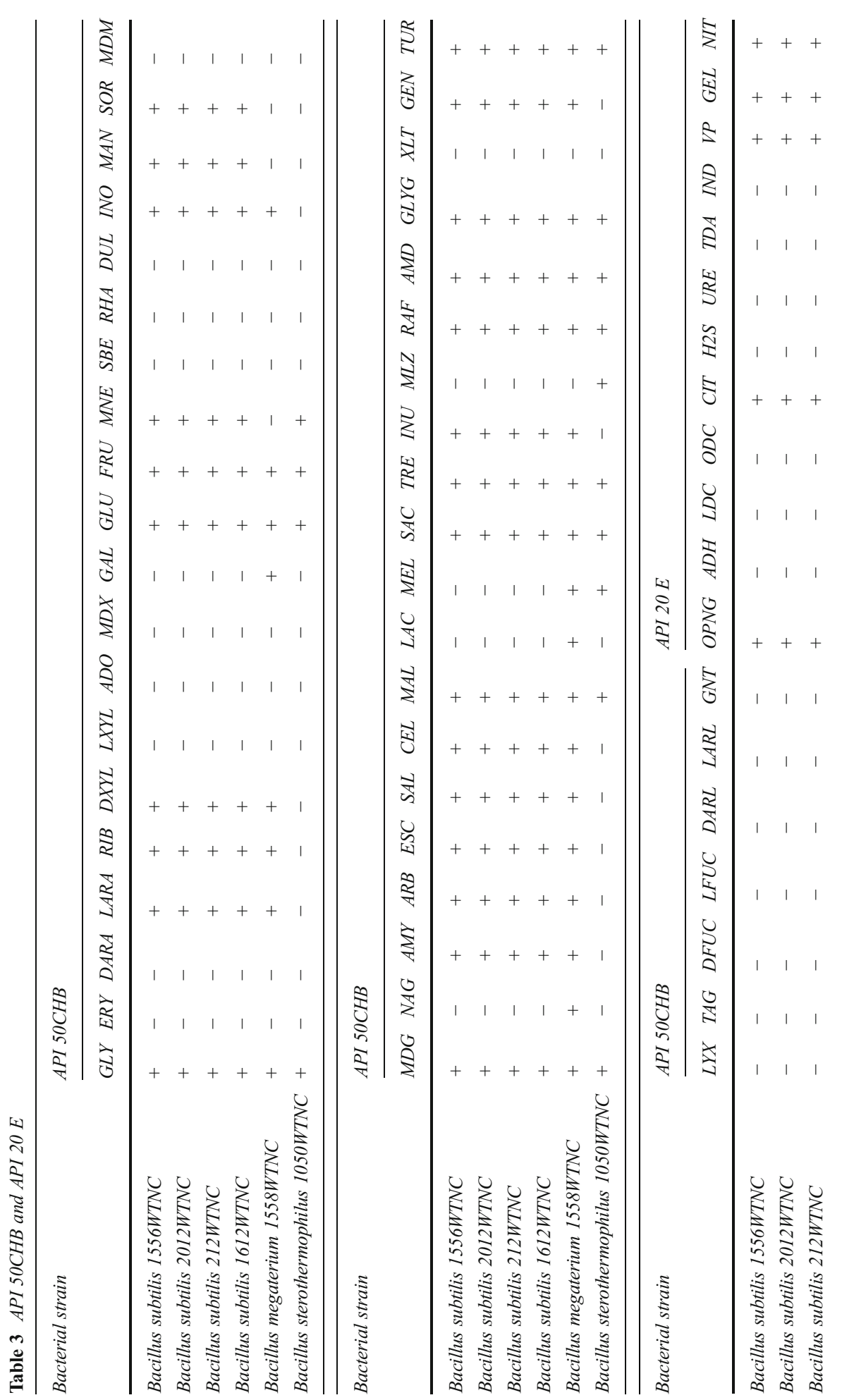




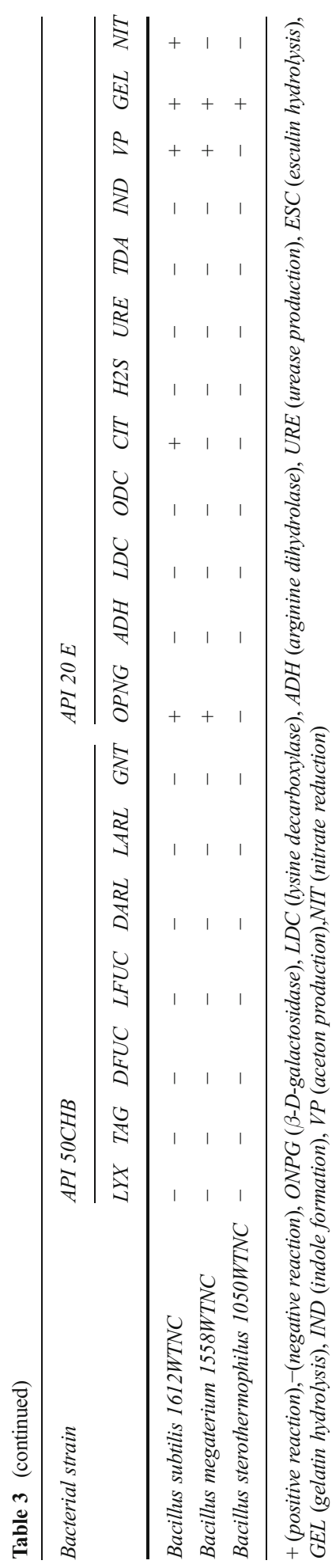




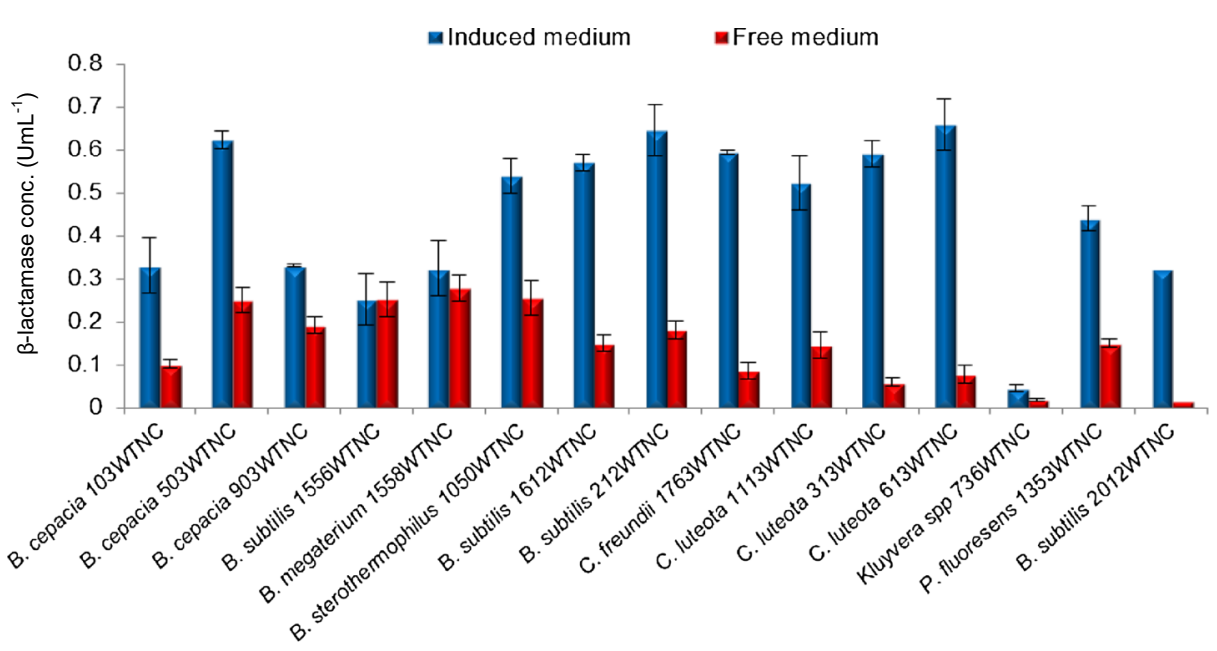

Bacterial strains

Fig. 2 Production of $\beta$-lactamase by acclimatized bacterial strains in DCY media containing cephalexin $\left(1 \mathrm{~g} \mathrm{~L}^{-1}\right)$ (inducibly) and DCY medium containing glucose $\left(1 \mathrm{~g} \mathrm{~L}^{-1}\right)$ (Genetically)

the enzyme in the absence of cephalexin (as inducibly). B. subtilis 1556 WTNC did not differ significantly in the amount of $\beta$-lactamase produced in the free and induced medium ( $0.25 \mathrm{vs}$. $0.26 \mathrm{U} \mathrm{mL}^{-1}$ ), respectively and considered as producing $\beta$-lactamase genetically.

The ability of bacterial strains to grow and produce $\beta$-lactamase in treated sewage effluent media (ECY) containing $1 \mathrm{~g} \mathrm{~L}^{-1}$ of cephalexin and $1 \mathrm{~g} \mathrm{~L}^{-1}$ of yeast extract as growth factor was also studied (Fig. 3). Among 14 bacteria isolates, ten isolates have the ability to produce a

\section{Enzyme activity $\quad$ Bacterial growth}

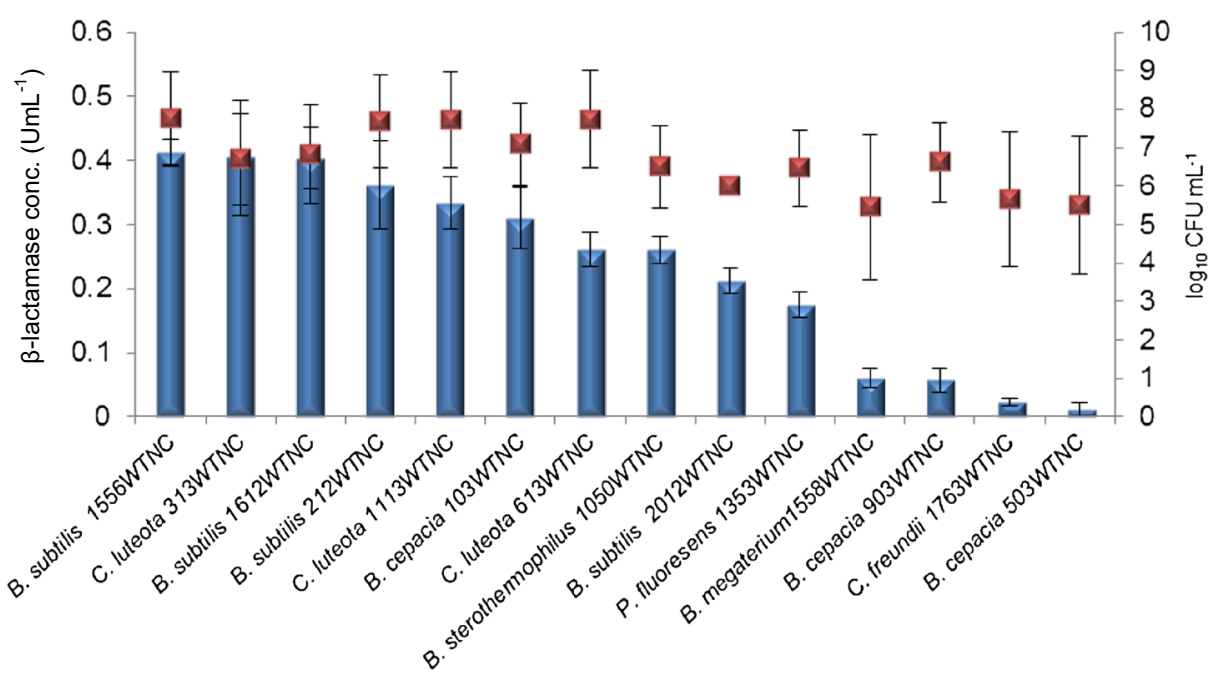

\section{Bacterial strains}

Fig. 3 Production of $\beta$-lactamase and microbial growth in effluent medium (ECY media) containing cephalexin $\left(1 \mathrm{~g} \mathrm{~L}^{-1}\right)$ by acclimatized bacterial strains 
detectable amount of $\beta$-lactamase. The production of $\beta$-lactamase among Gram-positive bacterial strains was more frequent than among Gram-negative bacteria. B. subtilis 1556WTNC, B. subtilis 1612WTNC, B. subtilis 212WTNC, C. luteola 1113WTNC, $B$. cepacia $103 \mathrm{WTNC}$ and $C$. luteola $313 \mathrm{WTNC}$ produced $\beta$-lactamase at levels above $0.333 \mathrm{U} \mathrm{mL}^{-1}$.

The bacterial strains that have produced $\beta$-lactamase in the treated sewage effluent medium (Fig. 2) were screened for enzymatic biodegradation of cephalexin in the treated sewage effluents containing $1 \mathrm{~g} \mathrm{~L}^{-1}$ of cephalexin (without nutrients). Eight bacterial strains were adapted to grow in the treated sewage effluents (Table 4$)$, and presented high growth $\left(>6 \log _{10}\right.$ $\mathrm{CFU} \mathrm{mL}^{-1}$ ), $\beta$-lactamase production and biodegradation of cephalexin at varying degree. These strains belong to four bacterial genera, Bacillus sp., Chryseomonas sp., Pseudomonas sp. and Burkholderia sp. A significant bacterial biodegradation was observed in cephalexin (ANOVA, $p<0.05$ ), in addition to a significant difference between the bacterial strains.

The results of the screening process can be summarized as follows: 68 bacterial isolates were obtained from treated sewage effluents. These isolates were screened to choose the most potent strains, which have the ability to biodegrade of antibiotics in sewage samples. Forty one bacterial isolates produced $\beta$-lactamase in DCY medium (Fig. 1), among them 15 bacterial strains were chosen and subjected to a series tests (Fig. 2), 10 bacterial strains produced $\beta$ lactamase in ECY medium (Fig. 3). These strains were screened to test the ability to biodegrade cephalexin in treated sewage effluents (Table 4.), eight bacterial strains (five isolates belong to Gram-positive bacteria and three belong to Gram-negative bacteria) have potential to biodegrade cephalexin in treated sewage effluents. Among those, B. subtilis 1556WTNC and B. subtilis 2012WTNC (Gram-positive bacteria), as well as B. cepacia 103WTNC, P. fluoresens 1353WTNC and C. luteola1113WTNC (Gram- negative bacteria), exhibited growth more than $6 \log _{10} \mathrm{CFU} \mathrm{mL} \mathrm{m}^{-1}$ and can biodegrade cephalexin in the treated sewage effluents more than others. Bacterial strain No.1556WTNC was selected and confirmed to be B.subtilis 1556WTNC (Accession NC_000964.3) according to 16S rRNA sequencing (Table 5 and Fig. 4).

Table 4 Biodegradation of cephalexin antibiotic by acclimatized bacterial strains obtained from treated sewage effluent samples

\begin{tabular}{|c|c|c|c|c|c|}
\hline Bacterial strains & $\begin{array}{l}\beta \text {-lactamase } \\
\text { concentration } \\
\left(\mathrm{U} \mathrm{mL}^{-1}\right)\end{array}$ & $\begin{array}{l}\text { Biodegradation } \\
(\%)\end{array}$ & $\begin{array}{l}\text { Final } \\
\mathrm{pH}\end{array}$ & $\begin{array}{l}\text { Bacterial growth } \\
\log _{10} \mathrm{CFU} \mathrm{mL} \mathrm{mL}^{-1}\end{array}$ & $\begin{array}{l}\text { Biomass yield } \\
(\mathrm{mg} / 100 \mathrm{~mL})\end{array}$ \\
\hline B. subtilis 1556WTNC $(+v e)$ & $0.78 \pm 0.07$ & $5.39 \pm 0.50$ & 4.64 & 7.17 & 26.0 \\
\hline B. subtilis 1612WTNC (+ve) & $0.35 \pm 0.06$ & $2.46 \pm 0.44$ & 5.00 & 5.48 & 20.0 \\
\hline B. subtilis 2012WTNC (+ve) & $0.63 \pm 0.08$ & $4.32 \pm 0.22$ & 5.50 & 6.76 & 25.0 \\
\hline $\begin{array}{l}\text { B. sterothermophilus 1050WTNC } \\
(+v e)\end{array}$ & $0.51 \pm 0.09$ & $3.53 \pm 0.67$ & 5.45 & 7.00 & 10.0 \\
\hline B. subtilis $212 \mathrm{WTNC}(+v e)$ & $0.57 \pm 0.04$ & $3.97 \pm 0.34$ & 4.70 & 5.00 & 20.0 \\
\hline C. luteola 1113WTNC (-ve) & $0.68 \pm 0.08$ & $4.75 \pm 0.58$ & 6.20 & 6.20 & 18.0 \\
\hline C. luteola 313WTNC (-ve) & $0.60 \pm 0.08$ & $4.17 \pm 0.61$ & 4.50 & $<3.00$ & 3.0 \\
\hline C. luteola 613WTNC (-ve) & $0.53 \pm 0.07$ & $3.68 \pm 0.54$ & 4.50 & $<3.00$ & 9.0 \\
\hline B. cepacia $103 \mathrm{WTNC}(-v e)$ & $0.82 \pm 0.05$ & $5.73 \pm 0.36$ & 6.30 & 6.079 & 18.0 \\
\hline P. fluoresens $1353 \mathrm{WTNC}(-v e)$ & $0.75 \pm 0.11$ & $5.23 \pm 0.74$ & 6.30 & 7.48 & 15.0 \\
\hline
\end{tabular}

\pm SD represent the standard division from the mean), (+ve) Gram-positive bacteria, ( $-v e)$ Gram-negative bacteria 
Table 5 Accession number of $B$. subtilis 1556WTNC

\begin{tabular}{lccccccc}
\hline Description & $\begin{array}{l}\text { Max } \\
\text { score }\end{array}$ & $\begin{array}{l}\text { Total } \\
\text { score }\end{array}$ & $\begin{array}{l}\text { Query } \\
\text { cover }\end{array}$ & $\begin{array}{l}\text { E value } \\
\text { valent }\end{array}$ & Accession \\
\hline $\begin{array}{l}\text { Bacillus subtilis subsp. subtilis str. 168 chromosome, } \\
\text { complete genome }\end{array}$ & 865 & 8,574 & $100 \%$ & 0.0 & $99 \%$ & NC_000964.3 \\
$\begin{array}{l}\text { Bacillus atrophaeus 1942 chromosome, complete } \\
\text { genome }\end{array}$ & 854 & 5,968 & $100 \%$ & 0.0 & $98 \%$ & NC_014639.1 \\
$\begin{array}{l}\text { Bacillus amyloliquefaciens FZB42, complete } \\
\text { genome }\end{array}$ & 843 & 7,522 & $100 \%$ & 0.0 & $98 \%$ & NC_009725.1 \\
$\begin{array}{l}\text { Bacillus licheniformis DSM 13=ATCC 14580 } \\
\text { chromosome, complete genome }\end{array}$ & 809 & 5,599 & $100 \%$ & 0.0 & $97 \%$ & NC_006322.1 \\
\hline
\end{tabular}

\subsection{Factors Affecting $\beta$-Lactamase Production}

The effect of different factors (inocula size, incubation period, incubation temperature and $\mathrm{pH}$ ) on the biodegradation of cephalexin was investigated in this work. The maximum $\beta$-lactamase concentration was recorded when $5.98 \log _{10} \mathrm{CFU} \mathrm{mL} \mathrm{mL}^{-1}$ was used as inoculum (Table 6.). However, the biodegradation of cephalexin at 2.99 and $5.98 \log _{10} \mathrm{CFU} \mathrm{mL} \mathrm{m}^{-1}$ did not differ significantly (as determined by ANOVA $p<0.05)$. However, biomass yield $(63.8 \mathrm{mg} / 100 \mathrm{~mL}$ ) was recorded with $2.99 \log _{10} \mathrm{CFU} \mathrm{mL}^{-1}$ of inoculum size. The linear regression analysis identified a significant relationship between $\beta$-lactamase concentration and biodegradation $\left(R^{2}=0.80 ; p<0.01\right)$.

The biodegradation of cephalexin after 10, 12 and 20 days did not differ significantly; it was 9.34, 9.40 and $8.33 \%$, respectively (as determined by ANOVA $p<0.05$ ) (Table 6.). However, the maximum $\beta$-lactamase concentration was noted after 20 days. The maximum yield of cell biomass was $95.6 \mathrm{mg} / 100 \mathrm{~mL}$ after 12 days. Bacterial growth was also increased from 4.48 to $7.48 \log _{10} \mathrm{CFU} \mathrm{mL} \mathrm{m}^{-1}$ with increasing incubation period from one day to 10 days. The linear regression analysis found that there is relation between the incubation period and $\beta$ lactamase concentrations $\left(R^{2}=0.86, p<0.05\right)$, biodegradation of cephalexin $\left(R^{2}=0.67\right.$, $p<0.05), \mathrm{pH}\left(R^{2}=0.77, p<0.01\right)$ and biomass $\left(R^{2}=0.65, p<0.05\right)$. However, the correlation coefficient between $\beta$-lactamase concentration and the biodegradation of cephalexin decreased with increasing incubation period from 12 to $20 \mathrm{~d}$ from 0.68 to 0.61 .

The maximum biodegradation of cephalexin, $\beta$-lactamase concentration, bacterial growth and biomass yield were detected at 30 and $35^{\circ} \mathrm{C}$ (Table 7.), which did not differ significantly

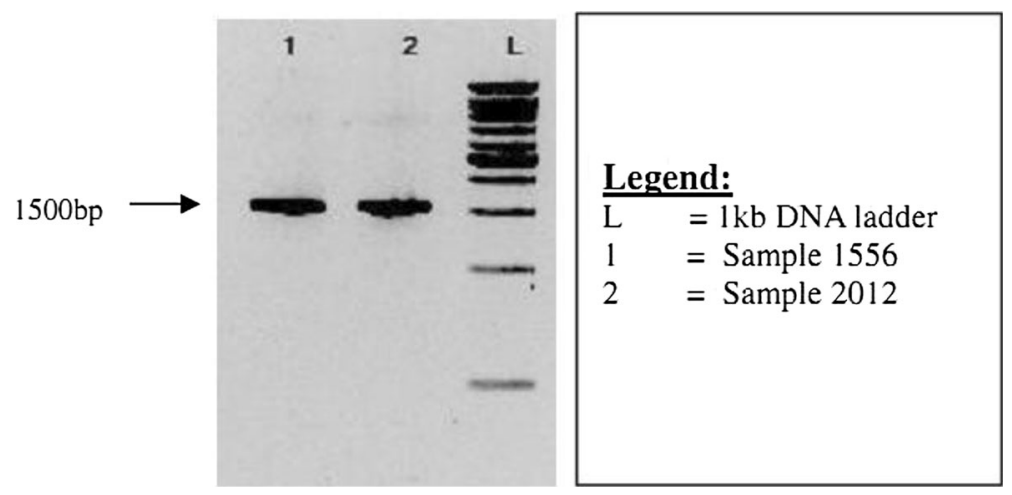

Fig. 4 Shown gel electrophoresis for the purified bacterial strains 
Table 6 Effect of initial concentration of $B$. subtilis 1556WTNC and incubation periods on $\beta$-lactamase, biomass yield and biodegradation of cephalexin $\left(1 \mathrm{~g} \mathrm{~L}^{-1}, \mathrm{w} / \mathrm{v}\right)$

\begin{tabular}{llllllc}
\hline Factor & & $\begin{array}{l}\beta \text {-lactamase } \\
\text { concentration } \\
\left(\mathrm{U} \mathrm{mL}^{-1}\right)\end{array}$ & $\begin{array}{l}\text { Biodegradation } \\
(\%)\end{array}$ & $\begin{array}{l}\text { Final } \\
\mathrm{pH}\end{array}$ & $\begin{array}{l}\text { Bacterial growth } \\
\left(\log _{10} \mathrm{CFU} \mathrm{mL}^{-1}\right)\end{array}$ & $\begin{array}{l}\text { Biomass yield } \\
(\mathrm{mg} / 100 \mathrm{~mL})\end{array}$ \\
\hline $\begin{array}{c}\text { Inocula concentration } \\
\left(\log _{10} \mathrm{CFU} \mathrm{mL} \mathrm{mL}^{-1}\right)\end{array}$ & 0.74 & $0.29 \pm 0.02$ & $4.04 \pm 1.06$ & 5.84 & 4.71 & 20.0 \\
& 1.49 & $0.26 \pm 0.08$ & $4.44 \pm 2.19$ & 6.63 & 5.27 & 42.2 \\
& 2.99 & $0.57 \pm 0.05$ & $9.18 \pm 1.28$ & 6.45 & 5.89 & 63.8 \\
& 5.98 & $0.74 \pm 0.03$ & $10.57 \pm 1.57$ & 6.54 & 7.48 & 53.7 \\
Incubation period & 7.42 & $0.22 \pm 0.07$ & $6.20 \pm 1.32$ & 6.11 & 7.48 & 36.4 \\
(day) & 1 & $0.18 \pm 0.03$ & $3.23 \pm 1.00$ & 7.00 & 4.48 & 0.20 \\
& 2 & $0.27 \pm 0.01$ & $3.62 \pm 0.08$ & 7.10 & 4.48 & 1.10 \\
& 4 & $0.19 \pm 0.01$ & $3.93 \pm 1.95$ & 6.00 & 5.60 & 7.70 \\
& 8 & $0.59 \pm 0.02$ & $5.81 \pm 0.65$ & 5.95 & 6.30 & 19.10 \\
& 10 & $1.14 \pm 0.13$ & $9.34 \pm 1.88$ & 5.51 & 7.48 & 9.00 \\
& 12 & $2.38 \pm 0.20$ & $9.40 \pm 1.28$ & 6.52 & 7.48 & 95.60 \\
& 20 & $2.68 \pm 0.33$ & $8.33 \pm 2.04$ & 6.17 & 7.48 & 80.30 \\
\hline
\end{tabular}

(as determined by ANOVA, $p<0.5$ ); the percentages of biodegradation were 10.97 and $11.40 \%$, respectively. The relationship between $\beta$-lactamase concentration and biodegradation process were correlated significantly $\left(R^{2}=0.98, p<0.01\right)$.

Biodegradation of cephalexin did not differ significantly in $\mathrm{pH}$ range 6 to 7.5 (as determined by ANOVA, $p<0.05$ ), (Table 7.). $\beta$-lactamase concentration also did not differ significantly at $\mathrm{pH} 6.5$ and 7. The maximum biomass yield $43.5 \mathrm{mg} / 100 \mathrm{~mL}$ was achieved at $\mathrm{pH}$ 7.0. Further increase in $\mathrm{pH}$ values to $\mathrm{pH} 8$ resulted in considerable decrease of the biodegradation of cephalexin.

Table 7 Effect of incubation temperature $\left({ }^{\circ} \mathrm{C}\right)$ and $\mathrm{pH}$ on $\beta$-lactamase, bacterial growth, biomass yield and biodegradation of cephalexin $\left(1 \mathrm{~g} \mathrm{~L}^{-1}\right.$, w/v) B. subtilis 1556WTNC

\begin{tabular}{|c|c|c|c|c|c|c|}
\hline Factor & & $\begin{array}{l}\beta \text {-lactamase } \\
\text { concentration } \\
\left(\mathrm{UmL}^{-1}\right)\end{array}$ & $\begin{array}{l}\text { Biodegradation } \\
(\%)\end{array}$ & $\begin{array}{l}\text { Final } \\
\mathrm{pH}\end{array}$ & $\begin{array}{l}\text { Bacterial growth } \\
\log _{10} \text { CFU mL }\end{array}$ & $\begin{array}{l}\text { Biomass yield } \\
(\mathrm{mg} / 100 \mathrm{~mL})\end{array}$ \\
\hline \multirow[t]{5}{*}{ Temperature $\left({ }^{\circ} \mathrm{C}\right)$} & 25 & $0.31 \pm 0.02$ & $3.63 \pm 0.94$ & 6.75 & 7.48 & 61.30 \\
\hline & 30 & $1.25 \pm 0.08$ & $10.97 \pm 0.93$ & 6.52 & 9.48 & 114.50 \\
\hline & 35 & $1.22 \pm 0.06$ & $11.40 \pm 0.54$ & 6.59 & 9.48 & 110.30 \\
\hline & 40 & $0.46 \pm 0.08$ & $4.22 \pm 0.01$ & 6.73 & 8.48 & 101.50 \\
\hline & 45 & $0.24 \pm 0.037$ & $2.71 \pm 0.84$ & 4.68 & 8.00 & 82.30 \\
\hline \multirow[t]{9}{*}{$\mathrm{pH}$} & 4 & $0.27 \pm 0.01$ & $4.32 \pm 0.14$ & 5.98 & 7.30 & 14.40 \\
\hline & 4.5 & $0.32 \pm 0.02$ & $4.81 \pm 0.33$ & 7.32 & 8.48 & 11.90 \\
\hline & 5 & $0.33 \pm 0.00$ & $4.21 \pm 0.65$ & 6.20 & 8.48 & 16.70 \\
\hline & 5.5 & $0.39 \pm 0.02$ & $4.63 \pm 1.12$ & 7.12 & 8.48 & 20.30 \\
\hline & 6 & $0.41 \pm 0.01$ & $5.28 \pm 1.16$ & 7.61 & 7.48 & 19.30 \\
\hline & 6.5 & $0.45 \pm 0.01$ & $7.34 \pm 1.60$ & 6.43 & 7.85 & 14.00 \\
\hline & 7 & $0.45 \pm 0.00$ & $5.64 \pm 0.77$ & 6.43 & 8.30 & 43.50 \\
\hline & 7.5 & $0.41 \pm 0.01$ & $7.03 \pm 1.44$ & 6.43 & 8.30 & 14.80 \\
\hline & 8 & $0.18 \pm 0.00$ & $3.26 \pm 1.16$ & 6.49 & 7.70 & 3.32 \\
\hline
\end{tabular}




\subsection{Biodegradability Studies}

The ability of $\beta$-lactamase produced by $B$. subtilis 1556 WTNC to biodegrade selected $\beta$ lactams antibiotics was tested in studying the potentials of this strain in the biodegradation of antibiotics in treated sewage effluents. Four $\beta$-lactams were selected: two of them belong to penicillins (amoxicillin and ampicillin) and two belong to cephalosporins (cephalexin and cefuroxime); ciprofloxacin (belonging to quinolones) was used as a negative control.

(a)

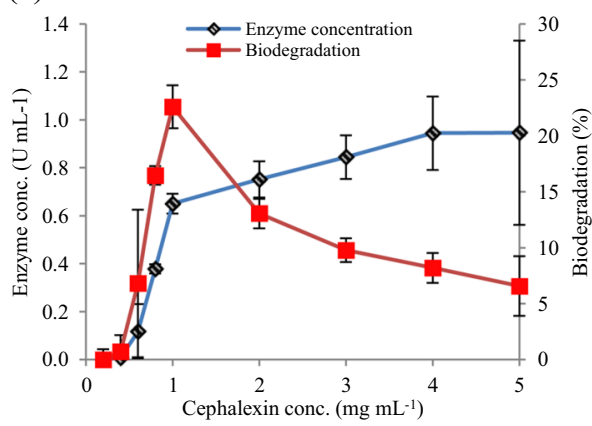

(c)

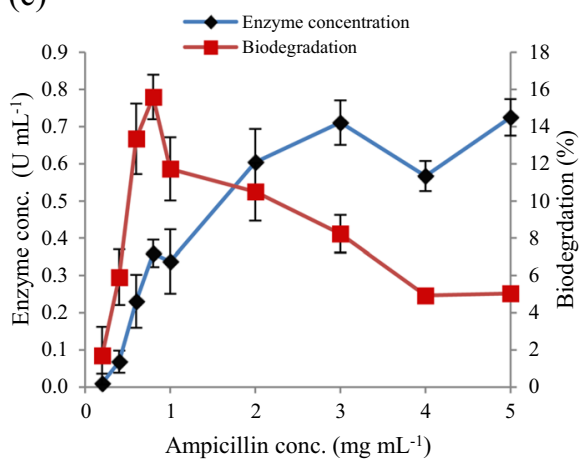

(b)

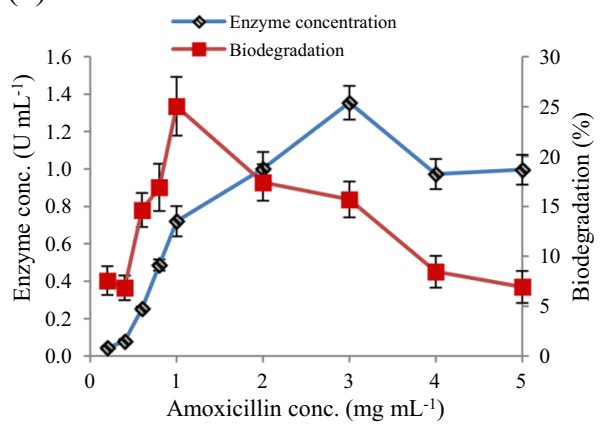

(d)

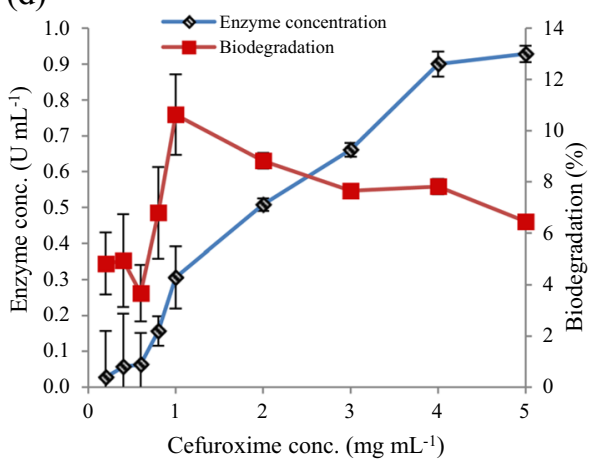

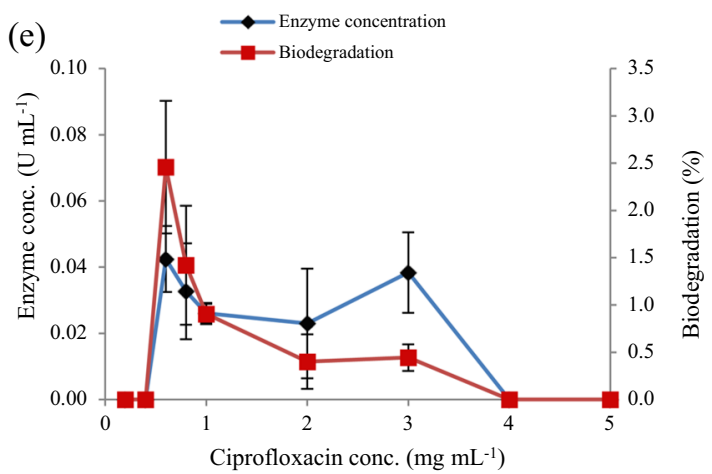

Fig. 5 Biodegradation of antibiotics in treated sewage effluent by B. subtilis $1556 \mathrm{WTNC}\left(5.98 \log _{10} \mathrm{CFU} \mathrm{mL} \mathrm{m}^{-1}\right.$, $\mathrm{pH} 6.5,35^{\circ} \mathrm{C}, 12$ days), (a) amoxicillin; (b) ampicillin; (c) cephalexin; (d) cefuroxime and (e) ciprofloxacin 
The maximum biodegradation of amoxicillin was recorded $25.03 \%$ at $1 \mathrm{mg} \mathrm{mL}^{-1}(\mathrm{w} / \mathrm{v})$, while maximum $\beta$-lactamase concentrations were $1.35 \mathrm{U} \mathrm{mL}^{-1}$ at $3 \mathrm{mg} \mathrm{mL}^{-1}(\mathrm{w} / \mathrm{v}$ ) (Fig. 5a). The initial concentrations of amoxicillin effected significantly the $\beta$-lactamase concentration $\left(R^{2}=0.50, p<0.05\right)$ and biodegradation process by $B$. subtilis $1556 \mathrm{WTNC}\left(R^{2}=0.44, p<0.05\right)$. The concentration of $\beta$-lactamase and biodegradation process have a strong positive relationship $\left(R^{2}=0.98, p<0.01\right)$ as determined by linear regression analysis. There was a significant correlation between bacterial growth and the concentration of $\beta$-lactamase $(p<0.05)$. The maximum bacterial growth $\left(5.7 \log _{10} \mathrm{CFU} \mathrm{mL}{ }^{-1}\right.$ ) (data not shown) and the maximum $\mathrm{pH}$ value (6.6) were recorded at the maximum biodegradation of amoxicillin. The maximum biomass yield $(5.2 \mathrm{mg} / 100 \mathrm{~mL})$ was obtained at the maximum concentration of the $\beta$-lactamase.

The maximum biodegradation (15.59\%) of ampicillin was shown at $0.8 \mathrm{mg} \mathrm{mL}^{-1}(\mathrm{w} / \mathrm{v})$ (Fig. 5b), while the maximum concentration of the $\beta$-lactamase was observed at $5 \mathrm{mg} \mathrm{mL}^{-1}$ $(\mathrm{w} / \mathrm{v})$, where $0.725 \mathrm{U} \mathrm{mL}^{-1}$ was recorded. Relationship studies indicated that there was a significant relationship between the ampicillin concentrations and amount of $\beta$-lactamase produced and the biodegradation percentage $\left(R^{2}=0.75, p<0.05\right)$. The bacterial growth at the maximum biodegradation $\left(8.4 \log _{10} \mathrm{CFU} \mathrm{mL} \mathrm{m}^{-1}\right)$ was more than that at the maximum $\beta$ lactamase concentration ( $7.4 \log _{10} \mathrm{CFU} \mathrm{mL} \mathrm{m}^{-1}$ ), while the $\mathrm{pH}$ did not differ significantly (in average 6.9). The initial concentration of ampicillin effected significantly the biomass yield $\left(R^{2}=0.82, p<0.01\right)$; the maximum yield $(20 \mathrm{mg} / 100 \mathrm{~mL})$ was observed at $5 \mathrm{mg} \mathrm{mL}^{-1}(\mathrm{w} / \mathrm{v})$.

The maximum biodegradation $(22.59 \%$ ) of cephalexin by $\beta$-lactamase produced by $B$. subtilis $1556 \mathrm{WTNC}$ was observed at $1 \mathrm{mg} \mathrm{mL}^{-1}$ (w/v) (Fig. 5c). The maximum $\beta$-lactamase concentration in treated sewage effluents containing different concentrations of cephalexin was achieved at a high of concentration $5 \mathrm{mg} \mathrm{mL}^{-1}\left(1.226 \mathrm{U} \mathrm{mL}^{-1}\right)$. The linear regression analysis showed a significant coefficient between the initial cephalexin concentrations and $\beta$-lactamase concentration and percentage of biodegradation $\left(R^{2}=0.76, p<0.01\right)$. The initial concentrations of cephalexin in treated sewage effluents also effected the biomass yield $\left(R^{2}=0.68, p<0.01\right)$.

The maximum biodegradation $(10.62 \%)$ of cefuroxime was recoded at $1 \mathrm{mg} \mathrm{mL}^{-1}$ (Fig. 5d). The maximum production of $\beta$-lactamase $\left(0.928 \mathrm{U} \mathrm{mL}^{-1}\right)$ was at $5 \mathrm{mg} \mathrm{mL}^{-1}$ $(\mathrm{w} / \mathrm{v})$, and the maximum biomass yield $(85 \mathrm{mg} / 100 \mathrm{~mL})$ was noted at $4 \mathrm{mg} \mathrm{mL}^{-1}(\mathrm{w} / \mathrm{v})$. The linear regression analysis found a strong relationship between the initial concentration of cefuroxime and $\beta$-lactamase concentrations and biodegradation $\left(R^{2}=0.96, p<0.01\right)$.

A ciprofloxacin antibiotic was used as a negative control because it belongs to the quinolone family and $\beta$-lactamase is not specific to degrade quinolone antibiotics. The maximum biodegradation and production of $\beta$-lactamase were $2.4 \%$ and $0.042 \mathrm{U} \mathrm{mL}^{-1}$, respectively, achieved at $0.6 \mathrm{mg} \mathrm{mL}^{-1}$ (w/v) (Fig. 5e). No significant correlation was noted between $\beta$-lactamase concentrations and the initial concentrations of ciprofloxacin. Bacterial growth was less than $3 \log _{10} \mathrm{CFU} \mathrm{mL} \mathrm{mL}^{-1}$ and the $\mathrm{pH}$ ranged from 6.1 to 8.6.

\section{Discussion}

Sewage treatment plants are responsible for causing antibiotic resistance to the natural environment (Laroche et al. 2009; Servais and Passerat 2009; Garcia-Armisen et al. 2011). This is because sewage coming to STPs contains many classes of antibiotics (Pauwels and Verstraete 2006). The results obtained in this work are in agreement with those of Al-Bahry et al. (2009) who stated that most bacterial isolates obtained from sewage exhibit resistance to antibiotics. The bacterial isolates studied in the present work were obtained from sewage treatment plants, which represent important sources for antibiotic-resistant bacteria as reported by Silva et al. (2006). Börjesson (2009) indicated that treated sewage effluents could provide 
favourable conditions for the growth of a diverse bacterial community, which constitutes a basis for the selection and spread of antibiotic resistance.

The explanations for the increase of resistance to cefuroxime among Gram-positive bacteria as it was found in the present investigation could be because cefuroxime is slightly less effective against Gram-positive bacteria (O'callaghan et al. 1976). The percentage of resistance to ampicillin among Gram-negative and Gram-positive bacteria was similar in this study (84.21 vs. $81.63 \%$ ). These results are supported by Sutherland and Rolinson (1964), who reported that the ampicillin has a broad-spectrum activity against both Gram-negative and Gram-positive bacteria.

The bacterial isolates studied here exhibited more resistance to cefuroxime and ampicillin compared to ciprofloxacin. Both cefuroxime and ampicillin belong to $\beta$-lactam antibiotics, which represent about $50 \%$ of the universal antibiotic consumption in the world (Livermore 1998; Livermore and Brown 2001). Ciprofloxacin is also effective against Gram-negative and Gram-positive bacteria (Kummerer et al. 2000; Kummerer 2003), but the usage of ciprofloxacin is less than $\beta$-lactam antibiotics. Therefore, the percentage resistance to cefuroxime and ampicillin in this study was more than that to ciprofloxacin. These findings are consistent with Velickovic-Radovanovic et al. (2009), who stated that the microbial resistance to antibiotics are correlated significantly with their utilization.

The multi-resistance towards antibiotics was observed by several studies. In the present study, $83.82 \%$ of the bacterial isolates exhibited multi-resistance to antibiotics (amoxicillin, ampicillin, cefuroxime and cephalexin). Similarly, previous study indicated that $97 \%$ of bacterial strains isolated from sewage were resistant to at least three antimicrobials (GarciaArmisen et al. 2011). Another study conducted by Rajbanshi (2008) found that $90 \%$ of bacteria from the oxidation ditch of a sewage treatment plant were multi-antibiotic resistant (penicillin, tetracycline, erythromycin, ampicillin, cotrimoxazole, ciprofloxacin, ampicillin and chloramphenicol). Al-Gheethi et al. (2013) found that all E. coli strains, $76.18 \%$ of TC, $66.66 \%$ of E. faecalis and $35 \%$ of Salmonella spp. isolated from treated sewage effluents were multi-resistant to cefuroxime, cephalexin and ampicillin.

In this work, more Gram-positive than Gram-negative bacteria exhibit multi-resistance to antibiotics under study (100 vs. $77.55 \%$ ). The differences between Gram-positive than Gramnegative bacteria in the resistance to antibiotics could be related to the differences in the structural characteristics of the cell wall, which influences the mechanisms of antibiotic resistance (Kaye et al. 2004).

The results obtained in this work indicate that the treated sewage effluents contain a high diversity of bacteria resistant to antibiotics. Thus, the antimicrobial resistance among the bacterial population in treated sewage effluents reflects the availability antibiotics in STPs. The disposal of treated sewage effluents into the environment may lead to contamination of natural waters by antimicrobial resistant bacteria. For this reason, the removal of antibiotics from treated sewage effluents should be performed before the disposal process into the environment. In the current study, the bacterial isolates that possessed the multi-resistance to antibiotics were subjected to study the potential to produce $\beta$-lactamase in order to choose most bacterial strains, which will be used to remove $\beta$-lactam antibiotics from treated sewage effluents.

The cephalexin was selected as a model to investigate the biodegradation of $\beta$-lactam antibiotics as function of $\beta$-lactamase, because Lin et al. (2009) and Guo et al. (2010) reported that the cephalexin is one of the most popular antibiotics that are ubiquitously present in sewage effluents at high concentrations due to its resistance to degradation during sewage treatment processes. The results found that 42 isolates presented high growth in the presence of $1 \mathrm{~g} \mathrm{~L}^{-1}$ of cephalexin. The bacterial tolerance to $1 \mathrm{~g}$ cephalexin $\mathrm{L}^{-1}$ has not been demonstrated 
before. However, D'Costa et al. (2006) found that among 480 strains of Streptomyces spp. 442 strains were resistant to seven antibiotics at $20 \mathrm{mg} \mathrm{L}^{-1}$ (w/v); among them was also cephalexin. Dantas et al. (2008) noted that some species of Burkholderia, Pseudomonas, Enterobacteriacea, Actinomycetes, Rhizobas and Sphingobacteria were reported to have the ability to tolerate $1 \mathrm{~g} \mathrm{~L}^{-1}$ (w/v) of 18 antibiotics; among them were penicillin and carbenicillin.

Among the 42 bacterial isolates, which showed tolerance for cephalexin, 41 bacterial isolates produced significant amounts of $\beta$-lactamase. These results indicate that $\beta$ lactamase is the main resistance mechanism to cephalexin among these isolates. $\beta$-lactamase is produced in a wide range of Gram-positive and Gram-negative bacteria with great variety of chemical, physical and enzymological properties (Doran et al. 1990; Toroglu et al. 2005; Liao et al. 2010). However, bacterial isolates No. 1354 and $844 \mathrm{~W}$ that exhibited high growth at $1 \mathrm{~g}$ cephalexin $\mathrm{L}^{-1}$, produced low concentrations of $\beta$-lactamase, both bacterial isolates might have the ability to resist cephalexin by other mechanisms and not by using $\beta$-lactamase. Levy (1992) and Kaye et al. (2004) stated that the ability of the bacterial cell to resist the antibiotics is caused by numerous mechanisms. The destruction, neutralization or inactivation of the antibiotic by $\beta$-lactamase is one of the resistance mechanisms. However, bacterial cells may change the active uptake/efflux mechanisms to grow in the presence of antibiotics.

The bacterial isolates were adapted to tolerate high concentrations of cephalexin $\left(1 \mathrm{~g} \mathrm{~L}^{-1}\right)$ to develop the efficiency of the bacterial isolates for the biodegradation of $\beta$-lactam antibiotics in different wastewaters, which may be contaminated with high concentrations of antibiotics such as pharmaceutical wastewaters. The ability of bacterial isolates to tolerate cephalexin and to produce $\beta$-lactamase indicates that these bacteria isolates could have a potential to biodegrade $\beta$-lactam antibiotics in treated sewage effluents.

$\beta$-lactamase can be either plasmid or chromosomally mediated, and its expression can be constitutive or inductive (Akindele et al. 2010). Some compounds are inducing (e.g., amoxicillin and cefoxitin), other compounds (e.g., piperacillin and cefotaxime) are poor inducers (Phillips and Shannon 1993). Therefore, the bioassay of production of $\beta$-lactamase inducibly or genetically was tested in the present study. B. subtilis $1556 \mathrm{WTNC}$ is considered to have genetically $\beta$-lactamase production, whereas strains $C$. luteota $313 \mathrm{WNTC}$ and $C$. luteota 613 WTNC produce $\beta$-lactamase inducibly.

The considerations in the enzymatic treatment of wastewaters are the presence of substrates, which may inhibit the growth and production of enzymes by the added bacterial strains (Morikawa 2006). Therefore, in the current study, the bacteria strains were tested to study the potential to grow and produce $\beta$-lactamase in treated sewage effluents. The production of $\beta$-lactamase in treated sewage effluent medium has not been performed before. However, a study of the production of amylase, protease and lipase in cassava wastewater by Bacillus subtilis LB5a and LB1a strains, conducted by Barros et al. (2013), found that both strains produce detectable amounts of the enzymes in comparison to the synthetic liquid medium. In the present study, ten bacterial strains, B. subtilis 1556WTNC (+ve), B. subtilis 1612WTNC (+ ve), B. subtilis 2012WTNC (+ve), B. sterothermophilus 1050WTNC (+ve), B. subtilis 212WTNC (+ve), C. luteola1113WTNC (-ve), C. luteola 313WTNC (-ve), C. luteola 613WTNC (-ve), B. cepacia 103WTNC (-ve), P. fluoresens $1353 \mathrm{WTNC}(-v e)$ produced high amount of $\beta$-lactamase concentrations in ECY medium. Eight bacterial strains presented high growth, $\beta$-lactamase production and biodegradation of cephalexin in treated sewage effluents.

It is known that some bacteria from an aquatic environment exposed to antibiotics develop the ability to degrade antibiotics (Nnenna et al. 2011). Thus, the results of the present work imply that the ability of these bacterial strains to biodegrade cephalexin was because these bacterial strains were acclimatized to tolerate cephalexin. Two types of enzymes are involved 
in the substrate degradation, exo-enzymes and endo-enzymes. Exo-enzymes are produced in the microorganism cell, but released outside the cell wall to solubilise insoluble particulates that are attached to the cell walls (Khalikova et al. 2005). Once solubilised, these substrates enter the microorganism cells where the degradation takes place by endo-enzymes (Gerardi 2003). In the current work, the biodegradation of cephalexin by bacterial isolates was determined as function of $\beta$-lactamase. From the environmental perspective, enzymes are more acceptable due to their biodegradability (Adam et al. 1999). One of the simplest methods of administering an enzyme to the target effluent is to introduce the microorganism cells that produce the enzyme into the effluent directly (Mugdha and Usha 2012).

Among eight bacterial strains which have the ability to biodegrade cephalexin in treated sewage effluents, B.subtilis 1556WTNC was chosen because it is multi-resistant to antibiotics, produces $\beta$-lactamase genetically and inducibly and has the potential to produce $\beta$-lactamase in treated sewage effluents medium. Recently, B. subtilis was used in many applications, such as biosorption of heavy metals (Abdel-Monem and Al-ZubeiryAH 2010), fermentation of red bean by a fibrinolytic enzyme (Chang et al. 2012), and production of bacteriocin (Kindoli et al. 2012), phenolic acid decarboxylase (Frank et al. 2012) and chitinase enzyme (Chandrasekaran et al. 2012). Bacillus sp. was also used as model to study the biological activity of mixed ligand complexes of transition metal with 8-quinolinols and 5-alkoxumethyl-8-quinolinol (Patel et al. 2012) and as bio-control agent to protect plants from a variety of pathogens (Chen et al. 2012). In this work, B. subtilis 1556WTNC was isolated from treated sewage effluents, exhibited good growth $\left(<5 \log _{10} \mathrm{CFU} \mathrm{mL} \mathrm{m}^{-1}\right), \beta$-lactamase activity, biodegradation of cephalexin and biomass yield in treated sewage effluents, and was resistant against cefuroxime, cephalexin, ampicillin and amoxicillin.

In the present study, the factors affecting $\beta$-lactamase production were investigated. The optimal condition of production $\beta$-lactamase was recorded with $5.98 \log _{10} \mathrm{CFU} \mathrm{mL} \mathrm{mL}^{-1}$ of B. subtilis $1556 \mathrm{WTNC}$, at $\mathrm{pH} 6.5$ and $35^{\circ} \mathrm{C}$ after 12 days of incubation period. There are no studies conducted on the production of $\beta$-lactamase and biodegradation of cephalexin in treated sewage effluents by $B$. subtilis before. However, a study performed by Al-Ahmad et al. (1999) on the biodegradation of penicillin G in wastewater by Pseudomonas putida, found that the biodegradation increased with increased incubation period from 28 to 40 days. Ranade et al. (2013) found that the optimal conditions for the production of $\beta$-lactamase by E. coli in nutrient broth were at $\mathrm{pH} 7$ and temperature of $35^{\circ} \mathrm{C}$.

In this work, the biodegradation of cephalexin at acidic and neutral $\mathrm{pH}$ was more than at base $\mathrm{pH}$ 8. The maximum biodegradation of cephalexin in this work was recorded at 30 and $35{ }^{\circ} \mathrm{C}$. These results differ from those recorded by Mitchell et al. (2013), who found that ampicillin, cefalotin, and cefoxitin is hydrolyzed under ambient conditions ( $\mathrm{pH} 7$ and $25^{\circ} \mathrm{C}$ ). The half-lives of these antibiotics ranged from 5.3 to 27 days. Base-catalyzed hydrolysis rates were significantly greater than acid-catalyzed and neutral $\mathrm{pH}$ hydrolysis rates. These differences may be related to the type of antibiotics and nature of the degradation process. In the current study, the biodegradation of cephalexin was determined as function of $\beta$-lactamase produced from B. subtilis 1556WTNC, while Mitchell et al. (2013) studied the hydrolysis rate of ampicillin, cefalotin, and cefoxitin as a function of $\mathrm{pH}$ and temperature.

From these findings, it can be noted that the main factor affecting the production of $\beta$ lactamase and biodegradation of cephalexin was the incubation period. B. subtilis 1556WTNC, which was chosen as one of the most potent bacterial strains and was used to study these factors, exhibited many of the characteristics. It has the potential to grow, produce $\beta$-lactamase and biodegrade cephalexin at a wide range of $\mathrm{pH}$ (6 to 7.5), temperature (30$35^{\circ} \mathrm{C}$ ). These characteristics are similar to treated sewage effluent properties. This is because it was isolated from treated sewage effluents. Therefore, B. subtilis $1556 \mathrm{WTNC}$ is suitable to be 
used for the biodegradation of $\beta$-lactam antibiotics in the treated sewage effluents; this part is discussed in the next section.

The biodegradation of antibiotics as a function of $\beta$-lactamase produced by $B$. subtilis $1556 \mathrm{WTNC}$ was investigated in this work. $\beta$-lactamase is an enzyme that cleaves the $\beta$-lactam ring and inactivates the antibiotic (Akindele et al. 2010). The biodegradation process of the antibiotic by $\beta$-lactamase is the main resistance mechanism in the majority of bacterial species. Several authors have reported that $\beta$-lactamase is a mechanism used by many bacteria to protect itself from action of $\beta$-lactam antibiotics (Gold and Moellering 1996; Akindele et al. 2010).

In this study, the biodegradation of penicillin's (amoxicillin) was more than that of cephalosporins (cephalexin and cefuroxime). These findings are accepted by Deshpande et al. (2004), who depicted that most of the $\beta$-lactamases from various species of Bacillus degrade natural penicillins faster than cephalosporins. This is because cephalosporins are significantly less sensitive to hydrolysis by various $\beta$-lactamases of different origin than penicillins (Bush et al. 1995). However, the rate of hydrolysis by $\beta$-lactamase varies considerably with different cephalosporins (Cimarusti 1984).

Similar results were observed in the comparison of amoxicillin and ampicillin, where the biodegradation of amoxicillin was more than that of ampicillin. This is similar to the study conducted by Morse and Jackson (2004) who reported that amoxicillin has affinity for microbial degradation. On the other hand, the degradation of antibiotics depends on the type of antibiotic. Cephalexin, sulfamethoxazole and sulfadiazine were removed by biodegradation in both freshwater and saline sewage systems ( $\mathrm{Li}$ and Zhang 2010). However, some antibiotics are difficult to degrade, especially ciprofloxacin (Prado et al. 2009; Wu et al. 2009).

Biodegradation of $\beta$-lactam antibiotics by $\beta$-lactamase produced from $B$. subtilis has not been investigated before. However, Al-Ahmad et al. (1999) studied the biodegradation of penicillin $\mathrm{G}$ in the hospital sewage by $P$. putida. They found that the maximum degradation was $27 \%$ recorded after 28 days and $35 \%$ after 40 days. In this work, B. subtilis 1556WTNC was more efficient than P. putida, because it has the ability to biodegrade $25 \%$ amoxicillin after 12 days. Besides, Al-Ahmad et al. (1999) determined the biodegradation of penicillin $\mathrm{G}$ by the measurement of COD, while in this study the biodegradation was determined by measurement of the amount of amoxicillin degraded by $\beta$-lactamase.

Compared to other techniques used in degradation of antibiotics, $90 \%$ of amoxicillin at $0.5 \mathrm{mM}$ was removed from deionised water by ozonation (Andreozzi et al. 2005) and complete degradation of amoxicillin and ampicillin at $0.5 \mathrm{mg} \mathrm{mL}^{-1}(\mathrm{w} / \mathrm{v})$ and $\mathrm{pH} 3$ was achieved in aqueous solution by photo-Fenton process (Elmolla and Chaudhuri 2009). In the present study, the maximum biodegradation of amoxicillin and ampicillin was 25.03 and $15.59 \%$, respectively. In order to explain these differences, it could be noted that those techniques conducted on the degradation of antibiotics in the aqueous solution or deionised water, while in the current study the biodegradation of antibiotics was performed in treated sewage effluents. It can be reported that the biodegradation process in sewage effluents are partly inhibited in the comparison to deionised water or an aqueous solution, because of the presence of organic and inorganic constituents that compete for hydroxyl radicals. For example, Dimitrakopoulou et al. (2012) found that the degradation of amoxicillin $\left(10 \mathrm{mg} \mathrm{L}^{-1}\right)$ by UV-A/TiO 2 photo-catalysis in the secondary effluents decreased by at least $50 \%$ than in pure water during the same period.

Many of decomposing bacteria are available during sewage treatment in the stage of the biological process (secondary process) (Heritage et al. 2003). However, Bacillus spp. are industrially employed to produce enzymes under extreme ( $\mathrm{pH}$ and temperature) conditions (Banik and Prakash 2004). Bacillus spp. have developed strategies for survival in unfavourable environments. 


\section{Conclusions}

In conclusion, many of bacteria isolated from treated sewage effluents possess an important ecological quality and have shown tolerance to antibiotics and production of $\beta$-lactamase. $B$. subtilis $1556 \mathrm{WTNC}$ has the potential to biodegrade pharmaceutical residues (ampicillin, cephalexin, amoxicillin and cefuroxime) in treated sewage effluents. B. subtilis 1556WTNC has the ability to survive in unfavourable environments also, it is safe and non-pathogenic, and does not produce toxic by-products. The biodegradation of pharmaceutical residues in treated sewage effluents would produce effluents of higher quality than that achieved by secondary treatment process.

Acknowledgments The authors gratefully acknowledge the fellowship by TWAS-USM and the Ministry of Higher Education of Malaysia for the research project financial support under fundamental research grant scheme (FRGS) (203/PTEKIND/6711328).

\section{References}

Abdel-Monem MO, Al-ZubeiryAH A-GAA (2010) Biosorption of nickel by Pseudomonas cepacia 120S and Bacillus subtilis 117S. Water Sci Technol 61:2994-3007

Adam W, Lazarus M, Saha-Mollera C, Weichold O, Hoch U, Haring D, Schreier P (1999) Biotransformation with peroxidase. Adv Biochem Eng Biotechnol 63:73-108

Akindele AA, Adewuyi IK, Adefioye OA, Adedokunm SA, Olaolu AO (2010) Antibiogram and beta-lactamase production of staphylococcus aureus isolates from different human clinical specimens in a tertiary health institution in Ile-life, Nigeria. American-Eurasian J Sci Res 5:230-233

Al-Ahmad A, Daschner FD, Kummerer K (1999) Biodegradability of cefotiam, ciprofloxacin, meropenem, penicillin G, and sulfamethoxazole and inhibition of wastewater bacteria. Arch Environ Contam Toxicol 37: $158-163$

Al-Bahry SN, Mahmoud IY, Al-Belushi KIA, Elshafie AE, Al-Harthy A, Bakheit CK (2009) Coastal sewage discharge and its impact on fish with reference to antibiotic resistant enteric bacteria and enteric pathogens as bio-indicators of pollution. Chemosphere 77(11):1534-1539

AL-Gheethi AAS, Norli I, Lalunga J, Azieda T, Efaq AN, Ab Kadir MO (2013) Susceptibility for antibiotics among faecal indicators and pathogenic bacteria in sewage treated effluents. Water Pract Technol 8(1):1-6

Al-Gheethi AAS, Norli I, Lalung J, Megat-Azlan A, Nur-Farehah ZA, Ab Kadir MO (2014) Biosorption of heavy metals and cephalexin from secondary effluents by tolerant bacteria. Clean Technol Environ Policy 16(1):137-148

Andreozzi R, Canterino M, Marotta R, Paxeus N (2005) Antibiotic removal from wastewaters: the ozonation of amoxicillin. J Hazard Mater 122(3):243-250

APHA (1999) Standard methods for the examination of water and wastewater, 21 st edn. American Public Health Association, Washington, DC

Banik RM, Prakash M (2004) Laundry detergent compatibility of alkaline protease from Bacillus cereus. Microbiol Res 159(2):135-140

Barros FFC, Simiqueli APR, de Andrade JC, Pastore GM (2013) Production of enzymes from agroindustrial wastes by biosurfactant-producing strains of Bacillus subtilis. Biotechnol Res Int 2013: 1-9

Batt AL, Kim S, Aga DS (2007) Comparison of the occurrence of antibiotics in four full-scale wastewater treatment plants with varying designs and operations. Chemosphere 68(3):428-435

Börjesson S (2009) Antibiotic resistance in wastewater methicillin-resistant S. aureus (MRSA) and antibiotic resistance genes. Division of Medical Microbiology, Department of Clinical and Experimental Medicine. Faculty of Health Sciences. Linköping University. Linköping Sweden

Bush LM, Calmon J, Johnson CC (1995) Newer penicillins and beta-lactamase inhibitors. Infect Dis Clinic North Am 9:653-686

Çelik E, Çalik P (2004) Bioprocess and oxygen transfer characteristics in beta-lactamase production by Bacillus species. Biotechnol Process 20(2):491-499

Cha JM, Yang S, Carlson KH (2006) Trace determination of $\beta$-lactam antibiotics in surface water and urban wastewater using liquid chromatography combined with electrospray tandem mass spectrometry. J Chromatogr A 1115(1-2):46-57 
Chandrasekaran R, Revathi K, Nisha S, Kirubakaran SA, Sathish-Narayanan S, Senthil-Nathan S (2012) Physiological effect of chitinase purified from Bacillus subtilisagainst the tobacco cutworm Spodopteralitura Fab. Pestic Biochem Physiol 104(1):65-71

Chang CT, Wang PM, Hung YF, Chung YC (2012) Purification and biochemical properties of a fibrinolytic enzyme from Bacillus subtilis-fermented red bean. Food Chem 133(4):1611-1617

Chen Y, Cao S, Chai Y, Clardy J, Kolter R, Guo JH, Losick R (2012) A Bacillus subtilis sensor kinase involved in triggering biofilm formation on the roots of tomato plants. Mol Microbiol 85(3):418-430

Cimarusti CM (1984) Dependence of beta-lactamase stability on substructures within beta-lactam antibiotics. J Med Chem 27:247-253

Cokgor EU, Arslan-Alaton I, Karahan O, Dogruel S, Orhon D (2004) Biodegradability improvement of penicillin formulation effluent by ozonation. Fresenius Environ Bull 13(10):1053-1056

D’Costa VM, McGrann KM, Hughes DW, Wright GD (2006) Sampling the antibiotic resistome. Science 311(5759):374-377

Dantas G, Sommer MO, Oluwasegun RD, Church GM (2008) Bacteria subsisting on antibiotics. Science 320: 100-103

Deshpande AD, Baheti KG, Chatterjee NR (2004) Degradation of $\beta$-lactam antibiotics. Curr Sci 87:1684-1695

Dimitrakopoulou D, Rethemiotaki I, Frontistis Z, Xekoukoulotakis NP, Venieri D, Mantzavinos D (2012) Degradation, mineralization and antibiotic inactivation of amoxicillin by $\mathrm{UV}-\mathrm{A} / \mathrm{TiO}_{2}$ photocatalysis. $\mathrm{J}$ Environ Manag 98:168-174

Dodd MC, Buffle MO, von Gunten U (2006) Oxidation of antibacterial molecules by aqueous ozone: moietyspecific reaction kinetics and application to ozone-based wastewater treatment. Environ Sci Technol 40(6): 1969-1977

Doran JL, Leskiw BK, Aippersbach S, Jensen SE (1990) Isolation and characterization of a $\beta$-lactamase inhibitory protein from Streptomyces clavuligerus and cloning and analysis of the corresponding gene. J Bacteriol 172(9):4909-4918

Elmolla ES, Chaudhuri M (2009) Degradation of the antibiotics amoxicillin, ampicillin and cloxacillin in aqueous solution by the photo-Fenton process. J Hazard Mater 172(2-3):1476-1481

EPA US (2003) Control of pathogens and vector attraction in sewage sludge; 40 CFR Part 503. U.S. Environmental Protection Agency, Cincinnati, OH, 45268

Frank A, Eborall W, Hyde R, Hart S, Turkenburg JP, Grogan G (2012) Mutational analysis of phenolic acid decarboxylase from Bacillus subtilis (BsPAD), which converts bio-derived phenolic acids to styrene derivatives. Catal Sci Technol 2(8):1568-1574

Garcia-Armisen T, Vercammen K, Passerat J, Triest D, Servais P, Cornelis P (2011) Antimicrobial resistance of heterotrophic bacteria in sewage-contaminated rivers. Water Res 45:788-796

Gerardi MH (2003) The microbiology of anaerobic digesters. John Wiley and Sons Inc., New Jersey, pp 91-118

Giger W, Alder AC, Golet EM, Kohler HPE, McArdell CS, Molnar E (2003) Occurrence and fate of antibiotics as trace contaminants in wastewaters, sewage sludges, and surface waters. Chimia 57(9):485-491

Gobel A, Thomsen A, McArdell CS, Joss A, Giger W (2005) Occurrence and sorption behaviour of sulfonamides, macrolides, and trimethoprim in activated sludge treatment. J Environ Sci Technol 39:3981-3989

Gold HS, Moellering RC (1996) Antimicrobial-drug resistance. N Engl J Med 335(19):1445-1453

Guo W, Wang H, Shi Y, Zhang G (2010) Sonochemical degradation of the antibiotic cephalexin in aqueous solution. Water SA 36:651-654

Heritage J, Evans EG, Killington RA (2003) Microbiology in action. Cambridge University Press, New York

Karam J, Nicell JA (1997) Potential applications of enzymes in waste treatment. J Chem Technol Biotechnol 69: $1-41$

Karthikeyan KG, Meyer MT (2006) Occurrence of antibiotics in wastewater treatment facilities in Wisconsin, USA. Sci Environ 361(1-3):196-207

Kaye KS, Engemann JJ, Fraimow HS, Abrutyn E (2004) Pathogens resistant to antimicrobial agents: epidemiology, molecular mechanisms, and clinical management. Infec Dis Clin North Am 18(4):467-511

Khalikova E, Susi P, Korpela T (2005) Microbial dextran-hydrolyzing enzymes: fundamentals and applications. Microbiol Mol Biol Rev 69(2):306-325

Kindoli S, Lee HA, Kim JH (2012) Properties of Bac W42, a bacteriocin produced by Bacillus subtilis W42 isolated from Cheonggukjang. J Microbiol Biotechnol 22(8):1092-1100

Kummerer K (2003) Significance of antibiotics in the environment. J Antimicrob Chemother 52:5-7

Kummerer K, Al-Ahmad A, Mersch-Sundermann V (2000) Biodegradability of some antibiotics, elimination of the genotoxicity and affection of wastewater bacteria in a simple test. Chemosphere 40(7):701-710

Laroche E, Pawlak B, Berthe T, Skurnik D, Petit F (2009) Occurrence of antibiotic resistance and class 1, 2 and 3 integrons in E. coli isolated from a densely populated estuary (Seine, France). FEMS. Microbiol Ecol 68(1): $118-130$ 
Le-Minh N, Khan SJ, Drewes JE, Stuetz RM (2010) Fate of antibiotics during municipal water recycling treatment processes. Water Res 44:4295-4323

Levy SB (1992) Active efflux mechanisms for antimicrobial resistance. Antimicrob Agents Chemother 36(4): 695-703

Li B, Zhang T (2010) Biodegradation and adsorption of antibiotics in the activated sludge process. J Environ Sci Technol 44:3468-3473

Liao W, Jiang J, Xu Y, Yi J, Chen T, Su X, Pan S, Wei X, Li Y (2010) Survey for $\beta$-lactamase among bacterial isolates from Guangzhou, China hospitals between, 2005-2006. J Antibiot 63(5):225-229

Lin AYC, Yu TH, Lateef SK (2009) Removal of pharmaceuticals in secondary wastewater treatment processes in Taiwan. J Hazard Mater 167(1-3):1163-1169

Livermore DM (1998) $\beta$-lactamase-mediated resistance and opportunities for its control. J Antimicrob Chemother 41(Supple D):25-41

Livermore DM, Brown DF (2001) Detection of $\beta$-lactamase mediated resistance. J Antimicrob Chemother 48: 59-64

Mitchell SM, Ullman JL, Teel AL, Watts RJ (2013) pH and temperature effects on the hydrolysis of three $\beta$ lactam antibiotics: ampicillin, cefalotin and cefoxitin. Sci Total Environ 466-467:547-55

Morikawa M (2006) Beneficial biofilm formation by industrial bacteria Bacillus subtilis and related species. J Biosci Bioeng 101(1):1-8

Morse A, Jackson A (2003) Fate of a representative pharmaceutical in the environment. Final Report submitted to Texas Water Resources Institute. Texas Tech University, USA

Morse A, Jackson A (2004) Fate of amoxicillin in two water reclamation systems. Water Air Soil Pollut 157(14):117-132

Mugdha A, Usha M (2012) Enzymatic treatment of wastewater containing dyestuffs using different delivery systems. Sci Rev Chem Commun 2(1):31-40

Neu HC (1992) The crisis in antibiotic resistance. Science 257(5073):1064-1073

Nnenna FB, Lekiah P, Obemeata O (2011) Degradation of antibiotics by bacteria and fungi from the aquatic environment. J Toxicol Environ Health Sci 3(10):275-285

O'callaghan CH, Sykes RB, Griffiths A, Thornton JE (1976) Cefuroxime, a new cephalosporin antibiotic: activity in vitro. J Antimicrob Chemother 9(3):511-519

Ogawara H (1975) Production and property of beta-Lactamases in Streptomyces. Antimicrob Agents Chemother 8(4):402-408

Patel KB, Kharadi GJ, Nimavat KS (2012) Synthesis and description of transition metal complexes and antimicrobial studies. J Chem Pharm Res 4(5):2422-2428

Pauwels B, Verstraete W (2006) The treatment of hospital wastewater: an appraisal. J Water Health 4(4):405-416

Pehlivanoglu-Mantas EL, Elisabeth R, Hawley A, Deeb DL (2006) Formation of nitrosodimethylamine (NDMA) during chlorine disinfection of wastewater effluents prior to use in irrigation systems. Water Res 40:341-347

Phillips I, Shannon K (1993) Importance of beta-lactamase induction. Eur J Clin Microbiol Infect Dis 12:19-26

Prado N, Ochoa J, Amrane A (2009) Biodegradation and biosorption of tetracycline and tylosin antibiotics in activated sludge system. Process Biochem 44(11):1302-1306

Rajbanshi A (2008) Study on heavy metal resistant bacteria in guheswori sewage treatment plant. Our Nature 6:52-57

Ranade YA, Dharmadhikari SM, Wadegaonkar PA (2013) Screening, production, purification and characterization of beta-lactamase from uropathogenic E. coli. Eur J Exp Biol 3(1):434-442

Servais P, Passerat J (2009) Antimicrobial resistance of faecal bacteria in waters of the Seine river watershed (France). J Sci Environ 408(2):365-372

Silva MF, Tiago I, Verissimo A, Boaventura RAR, Nunes OC, Manaia CM (2006) Antibiotic resistance of enterococci and related bacteria in an urban wastewater treatment plant. FEMS Microbiol Ecol 55:322-329

Spongberg AL, Witter JD (2008) Pharmaceutical compounds in the wastewater process stream in Northwest Ohio. J Sci Environ 397:148-157

Sutherland R, Rolinson GN (1964) Activity of ampicillin in vitro compared with other antibiotics. J Clin Pathol 17(4):461-465

Toloti A, Mehrdadi N (2001) Wastewater treatment from antibiotics plant (UASB Reactor). Int J Environ Res 5(1):241-246

Toroglu S, Dincer S, Korkmaz H (2005) Antibiotic resistance in Gram- negative bacteria isolated from Aksu River in Turkey. Ann Microbiol 55(3):229-233

Velickovic-Radovanovic R, Petrovic J, Kocic B (2009) Correlation between antibiotic consumption and bacterial resistance as quality indicator of proper use of these drugs in inpatients. Vojnosanit Pregl 66(4):307-312

Watkinson AJ, Murby EJ, Costanzo SD (2007) Removal of antibiotics in conventional and advanced wastewater treatment: implications for environmental discharge and wastewater recycling. Water Res 41(18):4164-4176

Wu C, Spongberg AL, Witter JD (2009) Sorption and biodegradation of selected antibiotics in biosolids. J Environ Sci Health A 44(5):454-461 